\title{
INVESTIGATION OF INSECTICIDE LEACHING \\ FROM POTTED NURSERY STOCK AND AQUATIC \\ HEALTH BENEFITS OF BIORETENTION CELLS \\ RECEIVING NURSERY RUNOFF
}

\author{
By \\ GRANT MATTHEW GRAVES \\ B.S. Environmental Science \\ Oklahoma State University \\ Stillwater, OK \\ 2011 \\ Submitted to the Faculty of the \\ Graduate College of the
Oklahoma State University
in partial fulfillment of
the requirements for
the Degree of
MASTER OF SCIENCE \\ December, 2013
}




\section{INVESTIGATION OF INSECTICIDE LEACHING FROM POTTED NURSERY STOCK AND AQUATIC HEALTH BENEFITS OF BIORETENTION CELLS RECEIVING NURSERY RUNOFF}

Thesis Approved:

Jason Vogel

Thesis Adviser

Jason Belden

Eric Rebek 


\section{ACKNOWLEDGEMENTS}

I would first like to acknowledge and thank Dr. Jason Vogel for his invaluable support, mentorship, friendship, advice and knowledge. Secondly, I would like to express my sincere gratitude to Dr.'s Jason Belden and Eric Rebek for their mentorship and guidance throughout the project.

Additionally, to all of the graduate and undergraduate students who have helped me along the way, thank you. I would especially like to thank undergraduates Hanna Huling, Lizzie Hickman, Jeff Biggerstaff, Peter Storm, and Zoology graduate students Adam Simpson and Kristal Sieve.

Finally, I would like to mention and say thank you to all my friends and family who have given me the motivation and support throughout the entire process. Specifically, my parents, who have expressed love, courage, motivation and drive since the beginning of my time on this Earth. Also, I would like to thank my girlfriend, Alexandra Jones, for providing a shoulder to lean on, love, and encouragement every day. 
Name: GRANT MATTHEW GRAVES

Date of Degree: DECEMBER, 2013

Title of Study: INVESTIGATION OF INSECTICIDE LEACHING FROM POTTED NURSERY STOCK AND AQUATIC HEALTH BENEFITS OF BIORETENTION CELLS RECEIVING NURSERY RUNOFF

\title{
Major Field: ENVIRONMENTAL SCIENCE
}

\begin{abstract}
Tree nurseries and greenhouses within the USDA red imported fire ant (RIFA) quarantine zone are required to incorporate insecticides into their potting media to prevent artificial spread of RIFA. Bifenthrin and fipronil are two common insecticides that are incorporated into potting media. During irrigation and stormwater events, there is potential for insecticides to leach from nursery pots, resulting in contamination of nearby surface waters. In this study, occurrences of insecticides in simulated nursery runoff were compared for two irrigation strategies and two types of containers in single pot leaching and field runoff simulations. In addition, toxicity of pot leachate to the aquatic invertebrate, Hyallela azteca, was measured, and removal efficiencies of insecticides from bioretention cell media were evaluated. Overhead irrigation resulted in significantly higher concentrations than drip irrigation, and Root Maker® pots allowed more leaching as compared to standard slick-wall pots. However, in all tests, the average concentration of bifenthrin during 15 days of leaching in both pot and field simulations was greater than $200 \mathrm{ng} / \mathrm{L}$ - more than 100 -fold greater than the $\mathrm{LC}_{50}$ for H. azteca. Toxicity studies confirmed this level of toxicity. Higher amounts of compost, $20 \%$ and $40 \%$, in bioretention cell media resulted in greater percent reduction of both bifenthrin and fipronil. This study determined that management techniques may be able to limit the amount of insecticide that leaches from pots and runs off to receiving water bodies. Specifically, selection of appropriate pot types, irrigation strategies, or filtering runoff through bioretention cells may reduce contamination loads. Thus, further best management strategies such as use of bioretention cells are needed in nursery and greenhouse facilities to prevent surface water runoff from transporting toxic insecticides to nearby water bodies.
\end{abstract}

Keywords: Bifenthrin, Fipronil, Tree nursery, Runoff, Bioretention cell, Hyallela. 
TABLE OF CONTENTS

Chapter

Page

\section{PROJECT INTRODUCTION}

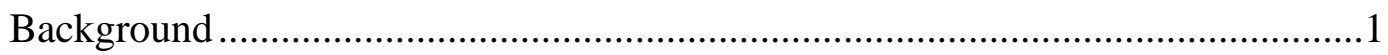

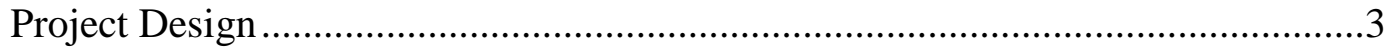

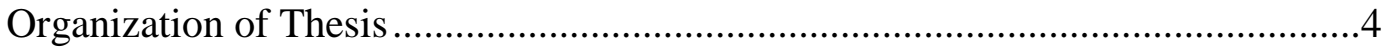

\section{BACKGROUND INFORMATION}

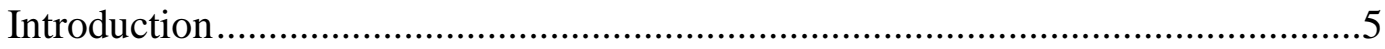

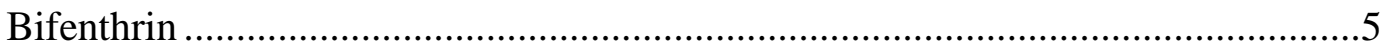

Environmental Fate of Bifenthrin ......................................................6

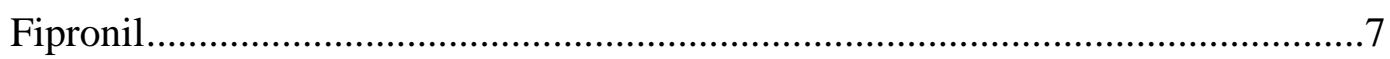

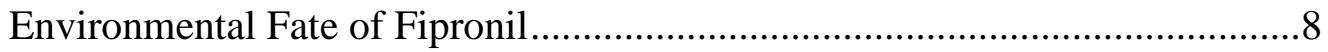

\section{INVESTIGATION OF INSECTICIDE LEACHING FROM POTTED NURSERY STOCK AND AQUATIC HEALTH BENEFITS OF BIORETENTION CELLS RECEIVING NURSERY RUNOFF}

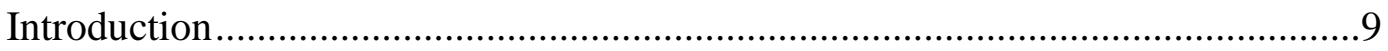

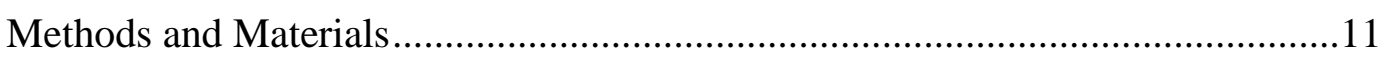

Potting Media Preparation .................................................................. 11

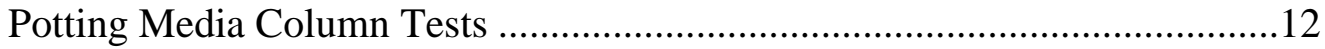

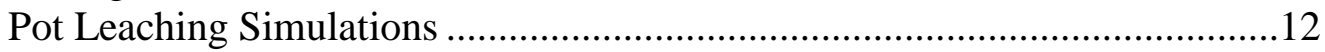

Nursery Runoff Simulations ................................................................ 13

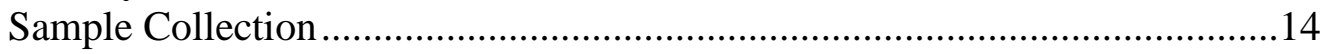

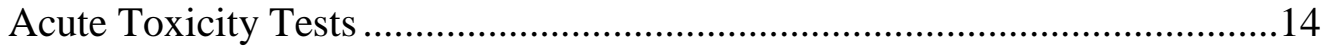

Bioretention Cell Media Column Studies ....................................................15

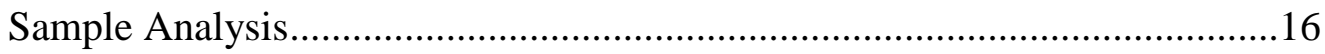

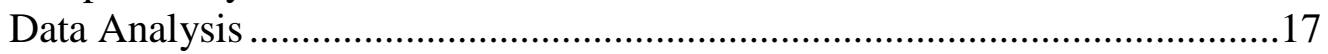

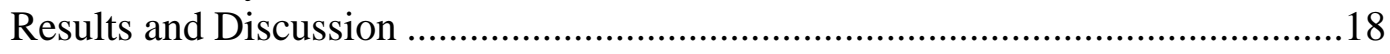

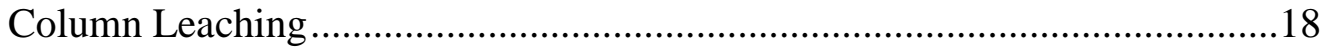

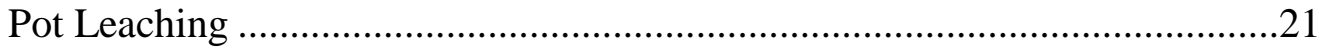




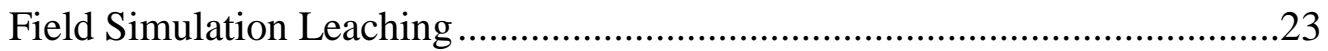

Factors Influencing Insecticide Runoff...............................................24

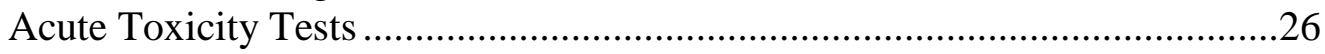

Environmental Implications ..................................................................28

Bioretention Cell Media Insecticide Removal ..............................................30

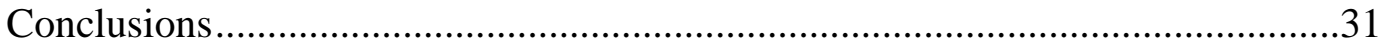

\section{LESSONS LEARNED}

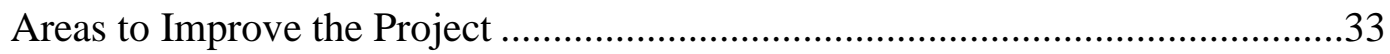

Ideas for Future Research ............................................................................ 34

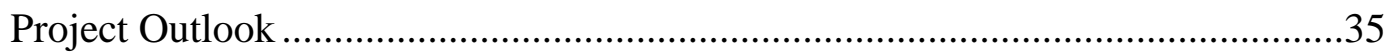

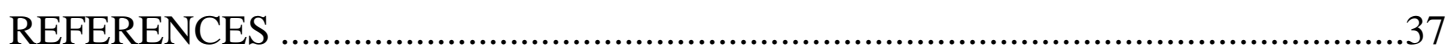

\section{APPENDICES}

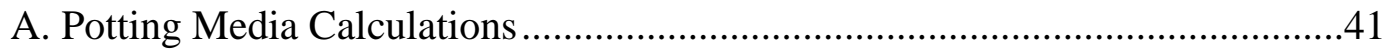

B. Potting Media Column Test Data..............................................................42

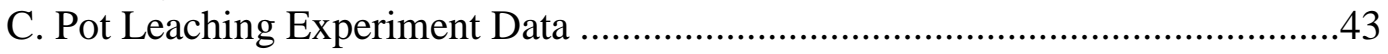

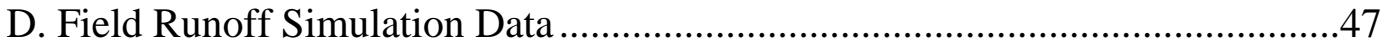

E. Bioretention Cell Media Column Test Data ................................................51

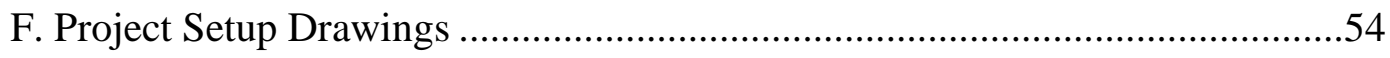




\section{LIST OF TABLES}

Table

2-1. Physical and chemical properties of bifenthrin. Directly from (Fecko 1999) ......7

2-2. Physical and chemical properties of fipronil. Directly from (Gunasekara and Troung 2007)

3-1. Leachate concentrations of Root Maker® with overhead irrigation (RMOH) and standard slick-wall pots with overhead irrigation (SWOH) with resulting $\mathrm{LC}_{50}$ based on dilutions of leachate. Two replications were performed for each pot and irrigation type combination; (a) represents pot leaching toxicity data and (b) represents runoff simulations toxicity data. Dilution is the dilution required to reduce the leachate effect to only cause $50 \%$ mortality. LC $_{50}$ was calculated by dividing leachate concentration by dilution. Note: dashes in (a) represent sample lost during processing; no data available. 


\section{LIST OF FIGURES}

Figure

Page

3-1. Log-log plot of mean ( \pm standard error) bifenthrin and fipronil concentrations versus 1-100 pore volumes. Note: Initial pot concentrations were 15 ppm bifenthrin and 1 ppm fipronil.

3-2. Mean bifenthrin and fipronil concentrations from column leachate versus median turbidity. Concentrations and turbidity readings shown are results from pore volume leachate. Note: Initial pot concentrations were 15 ppm bifenthrin and 1 ppm fipronil....

3-3. Mean ( \pm standard error) (a) bifenthrin concentrations and (b) fipronil concentrations in pot leachate from two different pot (Standard and Root Maker®) and irrigation types (Overhead and Drip) over 15 days. Note: bifenthrin incorporation in the pots initially before runs was 15 ppm bifenthrin and 1 ppm fipronil.

3-4. Comparison of pot (Standard and Root Maker®) and irrigation type (Overhead and Drip) versus (a) 15 day mean ( \pm standard error) bifenthrin concentrations and (b) fipronil concentrations in pot leachate.

3-5. Mean ( \pm standard error) (a) bifenthrin concentrations and (b) fipronil concentrations in field simulation leachate from two different pot (Standard and Root Maker®) and irrigation types (Overhead and Drip) over 15 days. Note: bifenthrin incorporation in the pots initially before runs was 15 ppm bifenthrin and 1 ppm fipronil.

3-6. Comparison of pot (Standard and Root Maker®) and irrigation type (Overhead and Drip) versus (a) 15 day mean ( \pm standard error) bifenthrin concentrations and (b) fipronil concentrations in field simulation leachate

3-7. Represents mean ( \pm standard error) percent reduction of (a) bifenthrin and (b) fipronil concentrations through four bioretention cell media compositions: sand(\%)/compost $(\%)$ by volume $(100 / 0,90 / 10,80 / 20$, 60/40) for 60 pore volumes. 


\section{CHAPTER I}

\section{PROJECT INTRODUCTION}

\section{Background}

Tree nurseries are required by the USDA to incorporate insecticides into their pots to prevent the shipping and transport of red imported fire ants. Consequently, the approved insecticides have shown to leach from the pots, and can have negative consequences for nearby waterbodies that receive runoff from irrigation and stormwater. In 2010, an Oklahoma tree nursery consulted with OSU's stormwater extension specialist, Dr. Jason Vogel, to develop a solution for reducing insecticide loads running off into nearby surface waters. Because of the advantage that bioretention cells can be retrofitted into an existing production, the Oklahoma nursery installed them at nursery runoff outlets to filter their irrigation and stormwater runoff to help reduce insecticides from reaching the adjacent stream. Shortly following installation, monitoring by the Oklahoma Department of Agriculture, Food and Forestry showed non-detects of bifenthrin in the nearby stream (unpublished data, Oklahoma Department of Agriculture, Food and Forestry, 2011). Following feedback and interest from nurseries, state agencies, and Oklahoma State research extension, ideas were suggested for future work on this project through research and monitoring of bioretention cells as an 
insecticide removal tool. As a result, a proposal was submitted and funded for research on using these systems as a part of a best management practice and integrated pest management technique.

\section{Project Design}

A funded, 2-year study from the Oklahoma Department of Agriculture's Integrated Pest Management (IPM) program was awarded to OSU's Biosystems and Ag Engineering program to investigate insecticide fate leaving nursery pots and removal efficiency and aquatic benefits of bioretention cells receiving nursery runoff. This project lies under the National Pesticide Program Stewardship program, and pertains to water quality issues in agriculture.

The overall objective of this project was to research management strategies to reduce aquatic health risks associated with insecticide use, especially in potted tree nurseries. The specific goals of the project included:

1. Investigation of pot management techniques and leaching of insecticides from potted nursery stock.

2. Evaluating the effectiveness and feasibility of using bioretention cells at nurseries as an IPM strategy for insecticide reduction.

3. Relaying information to the public and nursery industry to help improve aquatic health by implementing best management practices for insecticide reduction.

The tasks of the project to meet these goals and objective included: 
1. Investigation of various management options on pesticide leaching and transport in runoff using column studies and irrigation simulations.

2. Investigation of removal efficiency of insecticides from storm runoff by a laboratory investigation to compare the effectiveness of various typical and “designer pesticide-targeted" media on insecticide removal by bioretention cells.

3. Measurement of toxicity of simulated bioretention cell influent and effluent to Hyalella azteca.

\section{Organization of Thesis}

The thesis is organized into four chapters in regard to a journal article format. All included information preceding and following the journal article provides a framework for the project. Below are descriptions for chapters II-IV and appendices.

Chapter II: The objective of the background and literature review was to identify and introduce two common insecticides that are used in the nursery and greenhouse industry.

Chapter III: This chapter contains a publication currently under review in the journal of Environmental Science and Pollution Research titled "Investigation of Insecticide Leaching from Potted Nursery Stock and Aquatic Health Benefits of Bioretention Cells Receiving Nursery Runoff'. Authors included in this publication are G. Graves, J. Vogel, J. Belden, E. Rebek and A. Simpson.

Chapter IV: Lessons learned and suggestions for future work. 
Appendices: Appendix (A-E) includes background calculations and data for all experiments performed in this study. Appendix F includes line drawings for each experiment setup. 


\section{CHAPTER II}

\section{BACKGROUND INFORMATION}

The spread of red imported fire ants (RIFA), Solenopsis invicta, in the United States has increased rapidly due to transport and shipment of potted nursery stock (Lockley and Collins 1990). Historically, chlorinated insecticides such as DDT and chlordane that were used to control RIFA were banned in the 1970's in the U.S., and organophosphate insecticides were the replacement for agricultural pest control. With recent changes in regulations and agreements with the Environmental Protection Agency due to environmental concern in the 1980's and 1990's, newer generations of insecticides such as bifenthrin and fipronil are now used for RIFA control in nurseries (Calcott 2003). This chapter provides information regarding the environmental fate and mode of action for bifenthrin and fipronil.

\section{Bifenthrin}

Bifenthrin \{(2-methyl-3-phenylphenyl) methyl (1S,3S)-3-[(Z)-2-chloro-3,3,3trifluoroprop-1-enyl] -2,2-dimethylcyclopropane-1-carboxylate $\}$ is a third-generation synthetic pyrethroid insecticide developed and produced by the FMC Corp. (Figure 1). 
Common trade names in industry include Talstar ${ }^{\circledR}$, Brigade ${ }^{\circledR}$, and Ortho® Home Defense Max ${ }^{\mathrm{TM}}$. Bifenthrin is one of the pyrethroids that are currently sold to Certified Pesticide Applicators for uses such as RIFA control (Fecko 1999). Bifenthrin is considered a restricted use pesticide because of its high toxicity to aquatic species. Bifenthrin is in the class of pyrethroids and is often characterized by its ability to immobilize insect communities by causing nerve system damage (Miller 1985). The insecticide interferes with nerve cell endings and can effectively decrease neurotransmission causing paralysis (Salgado et al. 1983). Aquatic organisms are affected by bifenthrin because it can hinder ATPase enzyme production. ATPase enzyme production breaks down when pyrethroids are introduced and the organism is unable to maintain the ionic gradient between the cell walls leading to the aquatic organism's death (Siegfried 1993).

Environmental Fate of Bifenthrin

Bifenthrin is stable in aqueous and photolysis and only has one degradation product; 4'-hydroxy bifenthrin. Bifenthrin is known to strongly adsorb to soils and sediments because of its high $\mathrm{K}_{\mathrm{oc}}$. In almost all cases, bifenthrin exhibits a half-life greater than 100 days (Table 2-1). Half-lives in soil often depend on soil type, and has shown a longer half-life in soils with higher percentages of organic matter. In water, bifenthrin has a low solubility due to its high octanol-water coefficient and is considered stable. The aqueous photolysis half-life was shown to be greater than 250 days (Fecko, 1999). 
Table 2-1. Physical properties of bifenthrin. Directly from (Fecko 1999)

\begin{tabular}{|c|c|}
\hline \multicolumn{2}{|l|}{ Physical Properties } \\
\hline Molecular weight & 422.9 \\
\hline Water solubility (at $25^{\circ} \mathrm{C}$ ) & $0.1 \mathrm{mg} / \mathrm{L}$ \\
\hline $\begin{array}{l}\left.\text { Vapor pressure (at } 25^{\circ} \mathrm{C}\right) \\
\mathrm{mm} / \mathrm{Hg}\end{array}$ & $1.81 \times 10^{-7}$ \\
\hline Henry's constant $\left(\mathrm{pH} 7,25^{\circ} \mathrm{C}\right)$ & $7.20 \times 10^{-3} \mathrm{~atm} \mathrm{~m} / \mathrm{mol}$ \\
\hline Hydrolysis half-life (in natural water, at $\mathrm{pH} 6.7$ and $25^{\circ} \mathrm{C}$ ) & Stable \\
\hline Octanol-water coefficient (Kow) & $1.0 \times 10^{6}$ \\
\hline Anaerobic half-life & $97-156$ days \\
\hline Aerobic half-life & $65-125$ days \\
\hline Field dissipation half-life & 122 to 345 days \\
\hline Specific gravity $\left(\right.$ at $\left.25^{\circ} \mathrm{C}\right)$ & $1.212 \mathrm{~g} / \mathrm{ml}$ \\
\hline Bio-concentration factor (whole body, bluegill sunfish) & $6000 x$ \\
\hline Soil adsorption coefficient (Koc) & $1.31-3.02 \times 10^{5}$ \\
\hline Photolysis & 276-416 days \\
\hline
\end{tabular}

\section{Fipronil}

Fipronil \{5-amino-1-[2, 6-dichloro-4-(trifluromethyl) phenyl]-4[(trifluromethyl)sulfinyl]-1H-pyrazole $\}$ is a broad-spectrum, phenylpyrazole insecticide that is manufactured by the BASF chemical company. Originally, fipronil was discovered and developed by Rhône-Poulenc Agro in 1987, and placed under the market in 1993. Common trade names for fipronil in the nursery and agriculture industry include Termidor ${ }^{\circledR}$, Taurus ${ }^{\circledR}$, Chipco®, and Quali-Pro ${ }^{\circledR}$. Fipronil is also used in many other applications such as flea and tick, termite, mole cricket and corn pest control. Fipronil targets the GABA receptor of insects and blocks the chloride channels of neurons (Connelly 2001). Demonstrated effects include over-excitation of the central nervous system resulting in convulsions and paralysis of the organism (Gunasekara and Troung 2007). 


\section{Environmental Fate of Fipronil}

Fipronil dissipation includes four main degradation products: fipronil-sulfide (reduction), fipronil-desulfinyl (oxidation), fipronil-sulfone (biotic, oxidation), and fipronil-amide (biotic, hydrolosis). Fipronil's half-life is highly dependent on soil type or environment. Studies have shown fipronil has moderate mobility within soil with a $\mathrm{K}_{\mathrm{oc}}$ range of 427-1248 (mean of 825) and moderate water solubility (Rhone-Poulenc Ag Company; Ying and Kookana 2001) (Table 2). Fipronil's degredates are shown to have soil sorption coefficients greater than two to three times of fipronil and low water solubility (Bobe et al 1998). Fipronil is moderately water solubility with a range of 1.9$2.4 \mathrm{mg} / \mathrm{L}$ depending on $\mathrm{pH}$, and degrades quickly in water when exposed to UV light with an expected half-life of 6-8 hours (Gunasekara and Troung 2007) (Table 2-2).

Table 2-2. Physical and chemical properties of fipronil. Directly from (Gunasekara and Troung 2007).

\begin{tabular}{|c|c|c|}
\hline \multicolumn{2}{|c|}{$\begin{array}{l}\text { Chemical Abstract Service registry number (CAS \#) }{ }^{1} \\
\text { Molecular weight }(\mathrm{g} / \mathrm{mol})^{1}\end{array}$} & $\begin{array}{c}120068-37-3 \\
473.2\end{array}$ \\
\hline \multirow{4}{*}{ Solubility ${ }^{1}$} & Water $(\mathrm{mg} / \mathrm{L} ; \mathrm{pH}=5)$ & 1.90 \\
\hline & Water $(\mathrm{mg} / \mathrm{L} ; \mathrm{pH}=9)$ & 2.40 \\
\hline & Hexane $(\mathrm{mg} / \mathrm{L})$ & 28.0 \\
\hline & Toluene $(\mathrm{mg} / \mathrm{L})$ & 3000 \\
\hline \multicolumn{2}{|l|}{ Melting point $\left({ }^{\circ} \mathrm{C}\right)^{1}$} & $200-201$ \\
\hline \multicolumn{2}{|l|}{ Density $\left(\mathrm{g} / \mathrm{mL} 20^{\circ} \mathrm{C}\right)^{1}$} & $1.48-1.63$ \\
\hline \multicolumn{2}{|c|}{ Vapor pressure $\left(\mathrm{mPa}\right.$; calculated ${ }^{6}$} & $3.7 \times 10^{-4}$ \\
\hline \multicolumn{2}{|c|}{ Henry's constant $\left(\mathrm{m}^{3} \cdot \mathrm{atm} / \mathrm{mol} \text {; experimental }\right)^{2}$} & $6.60 \times 10^{-6}$ \\
\hline \multicolumn{2}{|c|}{ Henry's constant $\left(\mathrm{m}^{3} \cdot \mathrm{atm} / \mathrm{mol}\right.$; calculated ${ }^{6}$} & $8.50 \times 10^{-10}$ \\
\hline \multicolumn{2}{|c|}{ Octanol-water partition coefficient $\left(\log \mathrm{K}_{\mathrm{ow}}\right)^{6}$} & 3.50 \\
\hline \multicolumn{2}{|c|}{ Organic carbon normalized partition coefficient (averaged $\left.\mathrm{K}_{\mathrm{oc}}\right)^{3}$} & 825 \\
\hline \multicolumn{2}{|c|}{ Aqueous photolysis (days; $\mathrm{pH}=5)^{6}$} & 0.33 \\
\hline \multirow{6}{*}{ Hydrolysis half-life (days) ${ }^{4}$} & $\mathrm{pH}=5.5$ & $>100$ \\
\hline & $\mathrm{pH}=7.0$ & $>100$ \\
\hline & $\mathrm{pH}=9.0$ & 32.08 \\
\hline & $\mathrm{pH}=10$ & 4.75 \\
\hline & $\mathrm{pH}=11$ & 0.45 ( 11 hours) \\
\hline & $\mathrm{pH}=12$ & 0.1 (2.4 hours) \\
\hline \multicolumn{2}{|l|}{ Aerobic soil half-life (days) ${ }^{5}$} & 188 \\
\hline \multirow[t]{2}{*}{ Anaerobic soil half-life (days) ${ }^{2}$} & Dry flowable formulation & $19.3-22.2$ \\
\hline & Granular formation & 18.3 \\
\hline \multirow[t]{2}{*}{ Anaerobic water half-life (days) ${ }^{1}$} & Dry flowable formulation & $0.92-2.83$ \\
\hline & Granular formation & 5.20 \\
\hline
\end{tabular}




\section{CHAPTER III}

\section{INVESTIGATION OF INSECTICIDE LEACHING FROM POTTED NURSERY STOCK AND AQUATIC HEALTH BENEFITS OF BIORETENTION CELLS RECEIVING NURSERY RUNOFF}

\section{Introduction}

Pesticide use has become a great concern because it poses a significant threat as non-point source pollution. Pyrethroids and other insecticides are used often in agricultural and nursery industries where there is potential for runoff into nearby water sources (Gan 2006; Mangiafico et al. 2009). For example, due to artificial distribution and rapid spread of red imported fire ants (RIFA), Solenopsis invicta, the United States Department of Agriculture's Animal and Plant Health Inspection Service (APHIS) created regulations to incorporate an approved insecticide into insect management practices for nurseries under quarantine (Lockley and Collins 1990). Bifenthrin and fipronil are two commonly used insecticides in nurseries for control of RIFA and typically are incorporated into potting media (USDA 2007). With heavy irrigation and storm events on largely impervious surfaces at nursery sites, there is high potential for leaching and runoff of insecticides from planter pots (Kabashima et al. 2003). 
Research on sources and impacts of these insecticides are well documented (Budd et al. 2007, Bennett et al. 2005, Gan 2005), but there is limited information on their environmental fate in nursery containers and best management practices for controlling runoff. Recent studies have shown that pyrethroids and fipronil are highly toxic to aquatic invertebrates (Amweg 2006; Gan 2012; Weston 2005; Yang et al. 2006). Many nursery operations employ best management practices such as retention basins, flood control channels, and natural channels to control and manage runoff, but erosion and overflow of these nursery landscapes lead to sources of runoff (Lao et al. 2008). Therefore, it is critical to identify management strategies that reduce damage from insecticides to aquatic ecosystems.

Bennett et al. (2005) and Budd et al. (2009) showed that vegetated waterways and constructed wetlands greatly reduce the amount of insecticides leaving nursery and agriculture sites. Conversely, to the authors' knowledge no research has been completed on the mitigation of nursery runoff through bioretention cells. Bioretention cells are used typically as stormwater management devices, and have shown to be an effective physical and biological filter for removing suspended solids, nutrients, and pathogens (Hsieh and Davis 2005). Bifenthrin $\left(\mathrm{K}_{\mathrm{oc}}=1.3 \times 10^{5}\right)$ and fipronil metabolites $\left(\mathrm{K}_{\mathrm{oc}}=1300-1600\right)$ attach to suspended sediments and organic matter (Gan 2005; Lin et al. 2009; Yang et al. 2006). Fipronil, conversely, has a lower sorption potential $\left(\mathrm{K}_{\mathrm{oc}}=825\right)$ and higher water solubility, but still has shown to have limited mobility in soil and sediment (Ying and Kookana 2006). Hence, since bioretention cells are comprised of high percentages of organic matter, they may provide a new best management strategy for removal of insecticides from nursery and agricultural effluent. 
The objectives of this study were to evaluate the fate of bifenthrin and fipronil in a controlled nursery application, compare and contrast irrigation strategies and production techniques in nurseries, determine aquatic health impacts of nursery runoff through toxicity tests, and investigate the insecticide removal efficiency of bioretention media receiving runoff. Specifically, we performed column media leaching tests, pot leaching simulations, field runoff simulations, leachate toxicity tests on Hyallela azteza, and bioretention cell media column tests to meet these objectives.

\section{Methods and Materials}

Method design includes the setups for the four main objectives: potting media column tests, pot leaching simulations, nursery runoff simulations, acute toxicity tests, and bioretention cell media studies. In addition, this section contains potting media preparation techniques, sample collection procedures, and sample and data analysis for all studies. Drawings for all experimental setups can be found in Appendix F.

\section{Potting Media Preparation}

Potting media were pre-formulated and uniformly mixed on site at an Oklahoma tree nursery and donated for this project in 11.4-L Root Maker® pots (Root Maker Products Company, Huntsville, AL) and standard slick-wall pots. Media consisted of $90 \%$ pine bark chips and 10\% peat by volume. Dolomitic limestone was incorporated at $3.6 \mathrm{~kg} / \mathrm{m}^{3}$ into the media. Commercial grade Talstar ${ }^{\circledR} \mathrm{G}$ granules (FMC Corp., Philadelphia, PA) ( $0.2 \%$ bifenthrin by weight) were incorporated into the media with a commercial mixer at a rate of $15 \mathrm{ppm}$ at the Oklahoma nursery facility. Over 'n Out ${ }^{\circledR}$ fipronil granules (Garden Tech, Palatine, IL) (0.0143\% fipronil by weight) were 
uniformly incorporated into the potting media by hand mixing at a rate of $1 \mathrm{ppm}$.

Incorporation rates of bifenthrin and fipronil were based on the dry bulk density of the media $\left(0.26 \mathrm{~g} / \mathrm{cm}^{3}\right)$ and were calculated using the method described in the Imported Fire Ant (IFA) Manual (USDA 2007). Because only one insecticide is typically incorporated in nursery pots, $1 \mathrm{ppm}$ of fipronil was incorporated into the media, which is lower than the recommended rate minimum of $10 \mathrm{ppm}$ as stated in the IFA manual (USDA 2007). The lower rate allowed measurement of fipronil leaching potential, yet did not influence toxicity measurements of bifenthrin.

\section{Potting Media Column Tests}

Column studies were performed on the media for leachability of insecticides using a 30.5-cm long, 7.6-cm diameter, stainless steel pipe capped with a size 8 wire screen and a 12.7-cm diameter stainless steel funnel located at the bottom for catchment. The column was lightly packed with $20.3 \mathrm{~cm}$ of insecticide-inoculated media. A $2.5-\mathrm{cm}$ constant head of water was applied to the column to allow gravimetric flow and ensure complete contact of water to media throughout the column. A 1-L amber bottle was placed under the setup to collect the leachate. This procedure was replicated with three

columns and 100 pore volumes of water were added. Leachate samples were collected at $1,2,3,5,10,30$, and 100 pore volumes. One pore volume was determined as $600 \mathrm{~mL}$ based on the porosity $(66 \%)$ of the pine bark potting media.

\section{Pot Leaching Simulations}

Pesticide concentrations for single pot types and irrigation strategies were measured and compared for degree of insecticide leaching from the pots over a 15-day 
period. We evaluated Root Maker® pots and conventional slick-wall pots with two different irrigation regimes, overhead and drip irrigation. The overhead irrigation system consisted of a Gilmour® 7-pattern spray nozzle (Gilmour, Peoria, IL) set on the shower spray setting and attached to a ring stand at a height of $1 \mathrm{~m}$. A Raindrip ${ }^{\circledR}$ micro-spray irrigation kit (Rainbird Corporation, Azusa, CA) was used for drip irrigation. The overhead irrigation rate was $265 \mathrm{~L} / \mathrm{h}$ and the drip irrigation rate was $22.7 \mathrm{~L} / \mathrm{h}$. The average $\mathrm{pH}$ of irrigation water was 7.9 with a hardness of $200 \mathrm{mg} / \mathrm{L}$. Pots were placed in stainless steel $0.95-\mathrm{L}$ bowls with a pre-drilled $6.35 \mathrm{~mm}$ hole, and 24.6-L glass carboys were positioned beneath them for leachate catchment. We collected the first two pore volumes of leachate from the pots $(20.8 \mathrm{~L})$. Two pore volumes were calculated from the porosity $(66 \%)$ of the media in an 11.4-L pot and were determined to be $15.1 \mathrm{~L}$. All pots were irrigated daily, leachate was collected on days 1,2,3,5,10, and 15, and three replications were performed for each pot and irrigation type.

\section{Nursery Runoff Simulations}

Typically, nurseries store above-ground pots directly on top of landscape cloth with underlying, compacted soil. To simulate and evaluate runoff in a nursery setting, three replications of small-scale runoff simulations were performed, and irrigation and pot types were compared. For this study, plastic bins measuring $91 \mathrm{~cm} \mathrm{x} 61 \mathrm{~cm} \times 15 \mathrm{~cm}$ set at a 5\% slope were filled with Renfrow clay soil that was tightly compacted and covered with landscape fabric. The bins had a stainless steel tray measuring $61 \mathrm{~cm} \times 15$ $\mathrm{cm} \times 9 \mathrm{~cm}$ attached at the end with a $6.35 \mathrm{~mm}$ hole drilled in the bottom for drainage into a glass carboy. Each bin was arranged with four pots of the same type in an offset row. The overhead irrigation system was comprised of a rainfall pressure nozzle set at a height 
of $2 \mathrm{~m}$, and the drip irrigation was a Raindrip ${ }^{\circledR}$ micro-spray irrigation system. The overhead irrigation rate applied to each of the four pots was $56.8 \mathrm{~L} / \mathrm{h}$ and the drip irrigation rate for each pot was $7.6 \mathrm{~L} / \mathrm{h}$. A first-flush of $18.9 \mathrm{~L}$ of runoff water was collected for each pot and irrigation type bin.

\section{Sample Collection}

All samples for the pot leaching and field simulations were collected in 24.6-L glass carboys. Subsamples were split from the collected leachate for insecticide and water-quality analysis. To ensure a representative sample was analyzed, all carboys were lightly swirled and shaken before splitting samples. Collected samples were split from each carboy sample into 1-L amber glass bottles for analysis, and water-quality samples were split from carboy samples into 300-mL high-grade plastic bottles. Samples were stored in a refrigerator at $4^{\circ} \mathrm{C}$ for no more than 72 hours.

\section{Acute Toxicity Tests}

To determine the toxicity of leachate from two pot types (Root Maker® and standard), we performed static acute survival tests on the benthic amphipod, Hyalella azteca, following US Environmental Protection Agency methods (USEPA 2000). Amphipods were cultured within the laboratory according to standardized protocols (USEPA 2000). Organisms used in the tests were selected from a mixed-age culture using two sieves. A \#40 sieve was used to filter for appropriately sized organisms, while a \#60 sieve retained the desired amphipods. All sieved amphipods were housed separately for 4 days prior to use and fed 24 hours before each test. 
For each pot-leachate sample tested, a dilution curve (each step listed) was made using dechlorinated and charcoal-filtered tap water and stainless-steel measuring spoons resulting in final volumes of $340-600 \mathrm{~mL}$ contained in $800-\mathrm{mL}$ stainless steel containers. Each experimental unit (stainless steel container) contained ten amphipods and at each dilution there were three replicates. Stainless steel containers and measurement devices were used to reduce the loss of bifenthrin to container surfaces. Each test contained two controls: dechlorinated water and straight leachate acquired from untreated pots. Temperature remained at $23{ }^{\circ} \mathrm{C}\left( \pm 1^{\circ} \mathrm{C}\right)$ with a light cycle $16: 8$ hours (light:dark). Upon completion of the test, organisms that could not actively evade a probe were considered dead.

In addition to leachate tests, we conducted toxicity tests with bifenthrin and fipronil to establish expected toxicity based on concentration in laboratory water. Each test was performed using the same organisms, conditions, and experimental units as described for leachate studies. Concentrations tested for bifenthrin ranged from $0.75-24$ ng/L, while concentrations for fipronil ranged from 75-1200 ng/L. Ranges were based on established $\mathrm{LC}_{50}$ values for similar amphipods.

\section{Bioretention Media Column Studies}

Four different homogenized mixtures of bioretention media were evaluated for removal efficiency of insecticides in column studies. The mixtures included the following ratios of sieved sand to peat compost by volume: 100/0, 90/10, 80/20, and 60/40. A 25.4$\mathrm{cm}$ long, 7.6-cm diameter, stainless steel pipe was capped with a size 24 wire screen and a 12.7-cm diameter stainless steel funnel located at the bottom for catchment. Each of the 
mixtures was added to a height of $15.2 \mathrm{~cm}$ in the column. Three replications of pot leaching runs were performed to obtain 60 pore volumes of leachate for each of the column tests. Pore volumes were determined by the average porosities of the media: $35 \%$ for $100 / 0,36 \%$ for $90 / 10,37 \%$ for $80 / 20$, and $42 \%$ for $60 / 40$. From these calculations, one average pore volume was calculated as $263 \mathrm{~mL}$ for sample collection. A peristaltic pump was used to deliver a $2.54-\mathrm{cm}$ constant head of leachate water to the top of the column media. To account for low flow rates through the bioretention cell media, we constructed a constant head overflow by drilling a hole at $15.2-\mathrm{cm}$ on the side of the column and using $0.64-\mathrm{cm}$ plastic tubing to divert the influent back into the carboy. Samples of $525 \mathrm{~mL}$ (two pore volumes) were collected for pore volumes 1-2, 3-4, 10-11, 29-30, and 59-60 with 1-L amber glass bottles, and an additional $500 \mathrm{~mL}$ influent sample was collected from the peristaltic pump.

Sample Analysis

All solvents were purchased from Sigma Aldrich (St. Louis, MO, USA) and were reagent grade. Analytical standards for bifenthrin and fipronil were of high purity (>98\%), and were purchased from AccuStandard (New Haven, CT, USA). Following collection, $20 \mathrm{~g}$ of $\mathrm{NaCl}$ was added to all water samples, and samples were extracted using Agilent ${ }^{\circledR}$ Technologies 1000 mg C18 solid phase extraction cartridges. Each amber sample bottle was rinsed and shaken vigorously with $20-30 \mathrm{~mL}$ of ethyl acetate to remove residual insecticides from the sides of the glassware. The C18 cartridge was eluted with 9 $\mathrm{mL}$ of ethyl acetate and added to the solvent rinse, and 3-4 $\mathrm{g}$ of anhydrous sodium sulfate was added to the vial. Final extracts were evaporated to $1 \mathrm{~mL}$ with nitrogen and $40^{\circ} \mathrm{C}$ heat and analyzed using an Agilent 6850 Gas Chromatograph coupled with a 5975C 
Mass Spectrometer (Agilent, Palo Alto, CA USA) using electron ionization and selective ion monitoring (3- ion SIM) (bifenthrin: 181, 165, 166 and fipronil: 367, 369, and 213). Calibration standards for bifenthrin and fipronil were prepared at 30, 100, 300, and 1000 $\mu \mathrm{g} / \mathrm{L}$. Internal calibration was performed using Chrysene D12.

We conducted full quality control including use of a surrogate spike in all samples, conducting method blanks, laboratory spikes, and sample duplicates at a rate of $5 \%$ of samples. Mean recoveries in blank spikes were $96 \%(\mathrm{SD}=11)$ for bifenthrin and $103 \%$ (SD=6) for fipronil. Sample duplicate means were within $\pm 15 \%$ of original samples. The mean recovery of dibutyl chlorendate surrogate spike was $84 \%$ for all samples $(\mathrm{SD}=13)$.

Water-quality samples were taken to evaluate and compare additional parameters that may influence leachability of insecticides. Turbidity readings were taken using a Hach® 2100Q (Hach Company, Loveland, CO) handheld turbidity meter, and pH and specific conductivity were recorded using a Vernier@ Lab Quest multi-probe (Vernier Company, Beaverton, OR). Quality control for turbidity was ensured by replicating each reading 5 times, and $\mathrm{pH}$ and specific conductivity readings were duplicated at a rate of $5 \%$.

Data Analysis

Minitab® 16 (Minitab Inc., State College, PA) software was used to perform a two-factor ANOVA with a general linear model to compare pot types and irrigation strategies for differences among treatment groups $(\alpha=0.05)$. If differences existed, posthoc tests such as Tukey's multiple comparisons were used to assess variances. In 
addition, a regression analysis was performed on column media tests to identify if trends existed between turbidity and insecticide concentrations. Toxicity to pot leachate was quantified using the median lethal concentration $\left(\mathrm{LC}_{50}\right)$. We calculated $\mathrm{LC}_{50}$ values for each test using Probit Analysis (Society of Environmental Toxicology and Chemistry: Hazard Assessment Tools v1.0). For leachate samples, the $\mathrm{LC}_{50}$, reported as a dilution, was multiplied by measured sample concentration to obtain the leachate $\mathrm{LC}_{50}$.

\section{Results and Discussion}

\section{Column Leaching}

Both bifenthrin and fipronil exhibited a reduction in concentration over 100 pore volumes. A $\log -\log$ regression $\left(\mathrm{R}^{2}=0.99, \mathrm{R}^{2}=1\right)$ of mean bifenthrin levels and fipronil concentrations $\left(R^{2}=0.62\right)$ were shown over time throughout the column runs (Figure 3-1). Turbidity (Nephelometric Turbidity Units (NTU)) showed a strong correlation with column leachate bifenthrin concentrations $\left(\mathrm{R}^{2}=0.85, \mathrm{p}=0.001\right)$ (Figure 3-2). Fipronil was variable throughout the entire sampling period. The highest concentrations of fipronil were pore volumes 1-3, and the levels declined gradually with the lowest concentration at 100 pore volumes (Figure 3-1). A weak correlation was shown $\left(\mathrm{R}^{2}=.28, \mathrm{p}=0.29\right)$ between leachate fipronil concentrations and turbidity (Figure 3-2).

Bifenthrin and fipronil showed a higher release at the beginning of the runs due to leaching of the most available fractions of pesticide and potentially release of pesticides adsorbed to free particulate that was pushed from the column with the initial flush of water. Since both bifenthrin and fipronil were incorporated as granular formulations, release and dissolution from the formulation are additionally important to 
consider in regard to leaching potential. Bifenthrin exhibited a rapid $\left(\mathrm{y}=451 \mathrm{x}^{-1.21}\right)$ and slow fraction $\left(\mathrm{y}=54.1 \mathrm{x}^{-0.27}\right)$ relationships as pore volumes were added, indicating that bifenthrin may release from formulation at different rates. (Figure 3-1).

A strong correlation between bifenthrin concentrations and turbidity may indicate that bifenthrin is dependent on particulates or organic materials for transport through the water. Past studies have shown that pyrethroids strongly adsorb to suspended solids and sediments in runoff (Gan et al. 2005). Our results indicate that bifenthrin may demonstrate adsorption and desorption depending on available particles and organic matter moving through the column. The variations in fipronil concentrations may be due to moderate water solubility of the fipronil formulation and minute changes in hydrologic flow patterns (Gunasekara and Troung 2007). Furthermore, the spikes of fipronil as pore volumes were added could be in part due to the design of the slow-release granular formulation. In summary, bifenthrin and fipronil may adsorb and desorb moving through the column depending on binding sites available and disperse into solution depending on granular formulation properties. 


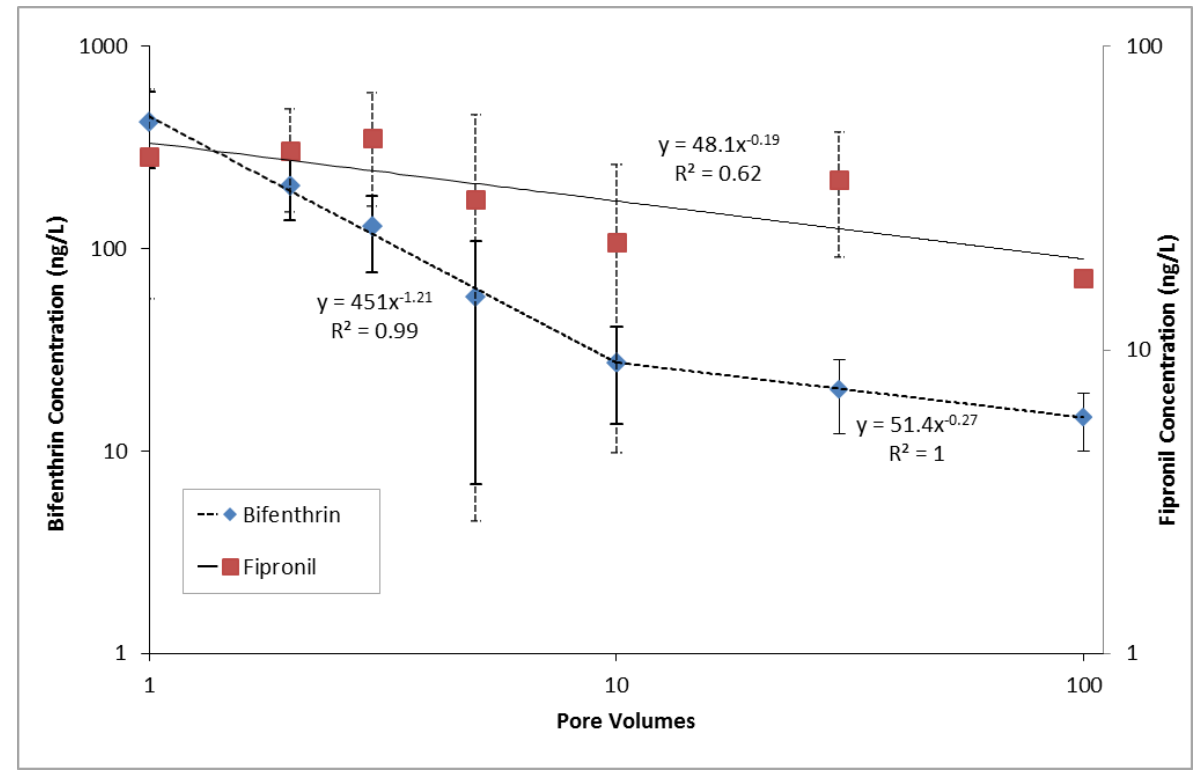

Figure 3-1. Log-log plot of mean ( \pm standard error) bifenthrin and fipronil concentrations versus 1-100 pore volumes. Note: Initial pot concentrations were 15 ppm bifenthrin and 1 ppm fipronil

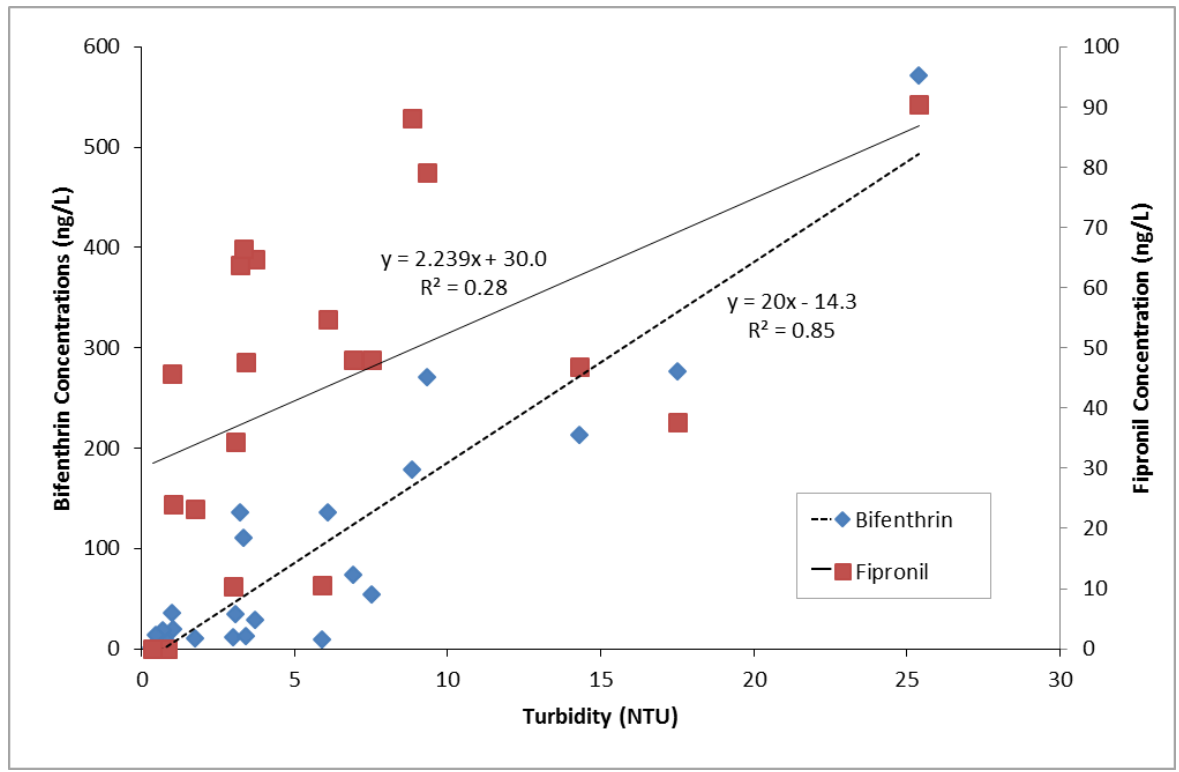

Figure 3-2. Bifenthrin and fipronil concentrations from three replications comparing column leachate versus median turbidity. Concentrations and turbidity readings shown are results from pore volume leachate. Note: Initial pot concentrations were $15 \mathrm{ppm}$ bifenthrin and 1 ppm fipronil. 


\section{Pot Leaching}

Specific conductivity was recorded for all leachate samples. The specific conductivity was variable with no consistent trend throughout the experiment with a range of 513-1142 $\mu \mathrm{S} / \mathrm{cm}$, with a median of $794 \mu \mathrm{S} / \mathrm{cm}$. Additionally, $\mathrm{pH}$ was consistent throughout all the samples with a range of 7.5 to 8.3 and median $\mathrm{pH}$ of 8.0 . No insecticides were detected for control blanks.

The concentrations of bifenthrin decreased over time $(\mathrm{p}=0.018)$, and significant $(\mathrm{p}<0.05)$ concentrations remained after 15 days of irrigation (Figure 3-3a). Bifenthrin concentrations were significantly different for pot type $(\mathrm{p}=0.039)$ and irrigation type $(\mathrm{p}<0.001)$ for all days. In general, bifenthrin concentrations in Root Maker® pots with overhead irrigation leachate demonstrated highest leaching potential, and were $21 \%$ higher than leachate concentrations in slick-wall with overhead irrigation (Figure 3-4a). Bifenthrin concentrations were lowest with standard slick-wall pots with drip irrigation, or $28 \%$ lower than Root Maker® pots with drip irrigation (Figure 3-4a). A strong correlation $\left(\mathrm{R}^{2}=0.84, \mathrm{y}=49.7 \mathrm{x}+210\right)$ was shown between turbidity levels and bifenthrin concentrations for the Root Maker® pots with overhead irrigation. Overall, turbidity readings were less than 10 NTU for all days sampled. Weak or no correlations $\left(\mathrm{R}^{2}<0.30\right)$ were shown between bifenthrin concentration and turbidity for any of the remaining pot and irrigation types.

Fipronil leachate concentrations were variable, with no significant trend indicated over the leaching period $(\mathrm{p}=0.052)$ (Figure $3-3 \mathrm{~b})$. However, there was a decreasing trend in fipronil concentrations when numerically comparing day 1, day 5, and day 15 levels. 
Additionally, no significant differences were shown for pot type $(\mathrm{p}=0.31)$ and irrigation type $(\mathrm{p}=0.24)$. Overall, Root Maker ${ }^{\circledR}$ pots with overhead irrigation resulted in the highest fipronil concentrations, and were $19 \%$ higher than slick-wall pots with overhead irrigation (Figure 3-4b). The other three (Root maker®/drip, slick-wall/overhead, slickwall/drip) pot and irrigation types resulted in similar means $( \pm 5 \%)$ of fipronil leachate levels (Figure 3-4b). Decreasing trends for turbidity and fipronil leachate concentrations were not indicated during the experiment.

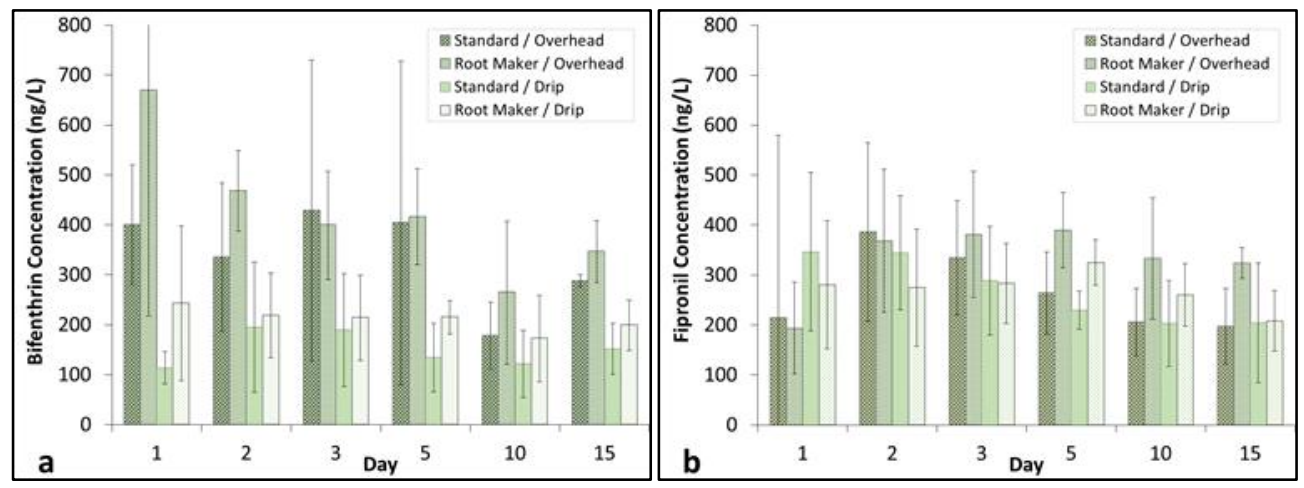

Figure 3. Mean ( \pm standard error) (a) bifenthrin concentrations and (b) fipronil concentrations in pot leachate from two different pot (Standard and Root Maker®) and irrigation types (Overhead and Drip) over 15 days. Note: bifenthrin incorporation in the pots initially before runs was 15 ppm bifenthrin and 1 ppm fipronil.

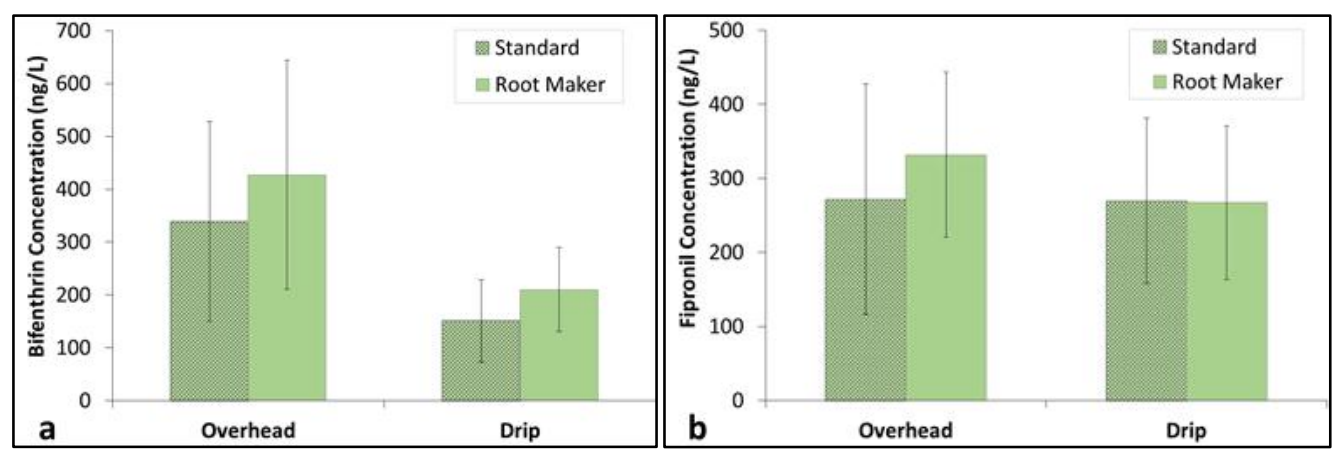

Figure 3-4. Comparision of pot (Standard and Root Maker®) and irrigation type (Overhead and Drip) versus (a) 15 day mean ( \pm standard error) bifenthrin concentrations and (b) fipronil concentrations in pot leachate. 


\section{Field Simulation Leaching}

Water quality readings for $\mathrm{pH}$ and specific conductivity were recorded for all samples, with no trends or relationships with insecticide leachate concentrations indicated. $\mathrm{pH}$ was uniform with a range of 7.7-8.2 and median of 7.8. Specific conductivity was variable with a range of $495-2560 \mu \mathrm{S} / \mathrm{cm}$ and a median of $1260 \mu \mathrm{S} / \mathrm{cm}$. Insecticides of interest were not detected in control blanks.

Bifenthrin levels remained constant, with no significant decrease in levels over time $(\mathrm{p}=0.989)$. Significant differences between irrigation $(\mathrm{p}<0.001)$ and pot type $(\mathrm{p}<0.001)$ were shown. Root Maker® and slick-wall pots with overhead irrigation showed highest overall bifenthrin levels by $48 \%$ and $49 \%$ compared to Root Maker® and slick-wall pots with drip irrigation, respectively (Figure 3-5a). Root Maker® pots with overhead irrigations resulted in the highest runoff bifenthrin concentrations, and were $29 \%$ higher than standard slick-wall pots with overhead irrigation (Figure 3-6a). No or weak correlations were determined between turbidity measurements and bifenthrin concentrations $\left(\mathrm{R}^{2}<0.30\right)$.

For fipronil, no significant decrease $(\mathrm{p}=0.46)$ was shown for fipronil levels over the sampling period. Significant differences were not shown when comparing pot types $(\mathrm{p}=0.067)$ and when comparing irrigation types $(\mathrm{p}=0.60)$. Numerical analysis showed no significant increase or decrease from day 1 to day 15 leachate regardless of pot or irrigation type (Figure 3-5b). Highest levels of fipronil were shown in Root Maker® with overhead and drip irrigation (Figure 3-6b). Fipronil concentrations were 7\% greater in Root Maker® pots compared with slick-wall pots with overhead irrigation, and 19\% greater on average in the Root Maker@ with drip irrigation as compared to standard pots 
with drip irrigation (Figure 3-6b). No correlation was shown $\left(\mathrm{R}^{2}<0.07\right)$ for fipronil leachate levels versus turbidity. It should be noted that for the entire run, median turbidity levels were higher on day 1 than day 15 for all runs, indicating higher sediment loadings.

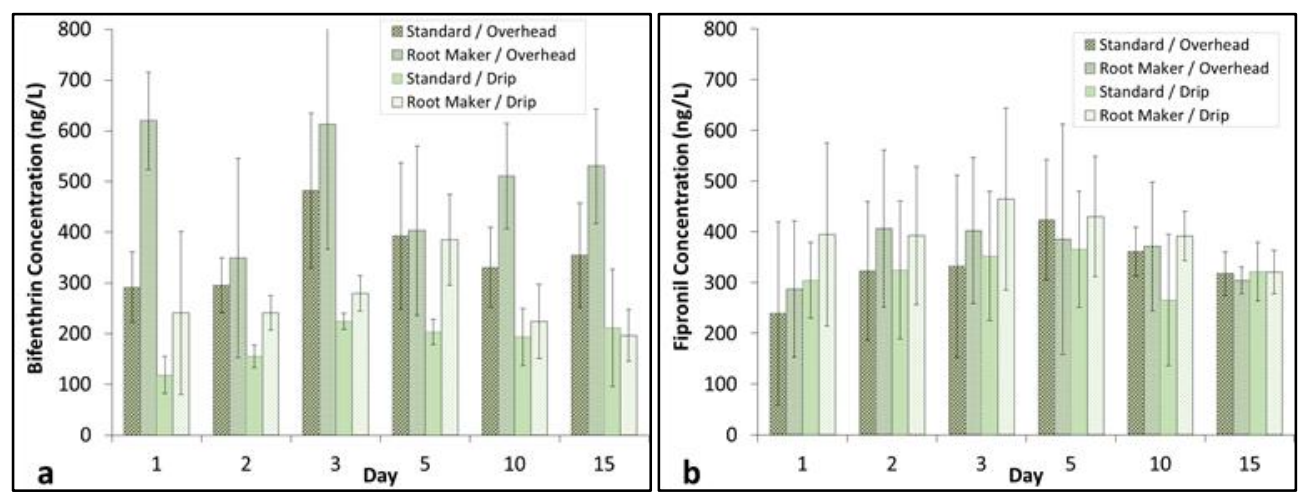

Figure 3-5. Mean ( \pm standard error) (a) bifenthrin concentrations and (b) fipronil concentrations in field simulation leachate from two different pot (Standard and Root Maker ${ }^{\circledR}$ ) and irrigation types (Overhead and Drip) over 15 days. Note: bifenthrin incorporation in the pots initially before runs was 15 ppm bifenthrin and 1 ppm fipronil.

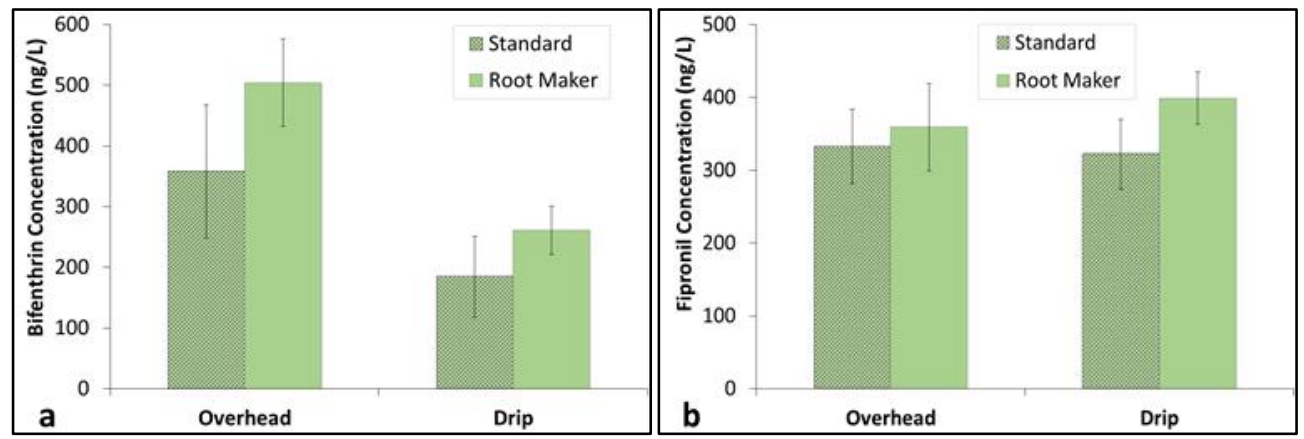

Figure 3-6. Comparision of pot (Standard and Root Maker®) and irrigation type (Overhead and Drip) versus (a) 15 day mean ( \pm standard error) bifenthrin concentrations and (b) fipronil concentrations in field simulation leachate.

Factors Influencing Insecticide Runoff

Overall, bifenthrin levels remained constant over the 15-day period in the runoff simulations, possibly due to the fact that higher loads of sediments from the clay soil bins 
were transported by the leachate. Gan (2006) expressed that suspended and dissolved solids adsorb a substantial amount of insecticides in surface water runoff from agricultural sites. Our results support this relationship that binding to the clay soil leveled off the amount of bifenthrin that is transported off site in surface runoff. In addition, the compost may serve as a dissolved organic carbon (DOC) source. Delgado (2010) found that DOC from gardening and agricultural amendments such as compost, peat, and mulches increased the potential for pyrethroids to leave in surface runoff in a solution phase. These relationships correlate to the highest concentrations of bifenthrin released from Root Maker® pots, which have additional vent holes on the sides to encourage root growth, and therefore, the potential to leach higher amounts of sediment and organic matter. Results from the pot leaching experiments show a high spike of bifenthrin during the first few days and a significant decrease over 15 days. Although significant decreases of bifenthrin throughout the run were shown, highest concentrations remained in leachate from Root Maker® pots with drip and overhead irrigation. Drip irrigation showed an average marginal increase from day 1 to day 5 before the concentrations remained steady throughout the runs.

Bifenthrin and fipronil levels in the runoff simulations from four pots were similar to the concentrations leaching from a single pot. Dilution from additional water running off the clay surface during overhead irrigation may have lowered the concentrations in the "first flush" that was captured. Drip irrigation water had less energy and more retention time through the media and across the clay bin. The runoff simulations were considered worst-case scenarios because of short overland flow, heavy irrigation, and capturing the first pore volumes leaving the pots. Although high concentrations were 
shown in both the pot leaching and runoff simulations, mean mass removal from each pot during leaching experiments over a 15 -day period was $0.09 \%$ and $0.12 \%$ for bifenthrin and fipronil, respectively. These results indicate that high levels of insecticide leaching could continue for a substantial amount of time.

Fipronil levels were variable throughout all of the experiments. Increased water solubility and lower soil organic carbon-water partitioning coefficient of fipronil $\left(\mathrm{K}_{\mathrm{oc}}=825\right)$ reduces the ability for this insecticide to be transported by soil particles (Gunasekara and Troung 2007). In essence, fipronil leaving the system was likely to be in a dissolved phase, or from granules leaving the pots. Fipronil concentrations were similar in both the drip and overhead irrigation strategies in both pot and field simulations ( $>0.24$ ), indicating that altering production practices may not be beneficial to limiting leaching potential of fipronil. No correlations were shown with turbidity, demonstrating that fipronil is leaving as a dissolved phase or volatilizing from the granules.

\section{Acute Toxicity Tests}

Control mortality was $<10 \%$ for all tests. Results from the bifenthrin and fipronilspiked laboratory water demonstrated the mean expected $\mathrm{LC}_{50}$ values as $1.5 \mathrm{ng} / \mathrm{L}$ and 322 ng/L, respectively. Since overhead irrigation strategies produced the highest levels of insecticides and sediment loads in runoff, the expected worst-case scenario, acute toxicity tests were only performed on two combinations: Root Maker® pots with overhead irrigation and standard slick-wall pots with overhead irrigation. Bifenthrin was determined as the driver for toxicity within these experiments. Although fipronil concentrations in leachate averaged $300 \mathrm{ng} / \mathrm{L}$, near the expected $\mathrm{LC}_{50}$, bifenthrin concentrations were always $100 \mathrm{x}$ the expected $\mathrm{LC}_{50}$ value. Thus, following dilution for 
bifenthrin, fipronil concentrations were negligible. Based on the dilution required to reduce toxicity to $50 \%$ lethality and the measured sample concentration, $\mathrm{LC}_{50}$ measurements can be made for each sample diluted. Pot leaching results showed a mean $\mathrm{LC}_{50}$ of $2.02 \mathrm{ng} / \mathrm{L}$, and the runoff simulation mean was $1.21 \mathrm{ng} / \mathrm{L}$. Resulting $\mathrm{LC}_{50}$ 's in the pot leaching and field simulations were all within a factor of two of the expected $\mathrm{LC}_{50}$ for bifenthrin, except for replicate 2 in the pot leaching. In both the pot leaching and runoff simulations, mean $\mathrm{LC}_{50}$ values decreased overall through days 1,5 , and 15 (Table 3). V

Table 3-3. Leachate concentrations of Root Maker® with overhead irrigation (RMOH) and standard slick-wall pots with overhead irrigation (SWOH) with resulting $\mathrm{LC}_{50}$ based on dilutions of leachate. Two replications were performed for each pot and irrigation type combination; (a) represents pot leaching toxicity data and (b) represents runoff simulations toxicity data. Dilution is the dilution required to reduce the leachate effect to only cause $50 \%$ mortality. $\mathrm{LC}_{50}$ was calculated by dividing leachate concentration by dilution. Note: dashes in (a) represent sample lost during processing; no data available.

\begin{tabular}{|c|c|c|c|c|c|c|c|c|c|c|c|c|c|}
\hline \multirow{2}{*}{$\begin{array}{c}R M O H \\
\text { Day }\end{array}$} & \multicolumn{2}{|c|}{ Leachate Conc. (ng/L) } & \multicolumn{2}{|c|}{ Dilution } & \multicolumn{2}{|c|}{$\mathrm{LC}_{50}(\mathrm{ng} / \mathrm{L})$} & \multirow{2}{*}{\begin{tabular}{|c|} 
SWOH \\
Day
\end{tabular}} & \multicolumn{2}{|c|}{ Leachate Conc. (ng/L) } & \multicolumn{2}{|c|}{ Dilution } & \multicolumn{2}{|c|}{$\mathrm{LC}_{50}(\mathrm{ng} / \mathrm{L})$} \\
\hline & Rep 1 & $\operatorname{Rep} 2$ & $\operatorname{Rep} 1$ & $\operatorname{Rep} 2$ & $\operatorname{Rep} 1$ & $\operatorname{Rep} 2$ & & $\operatorname{Rep} 1$ & $\operatorname{Rep} 2$ & $\operatorname{Rep} 1$ & $\operatorname{Rep} 2$ & $\operatorname{Rep} 1$ & $\operatorname{Rep} 2$ \\
\hline 1 & 391.07 & 425.91 & - & 65.6 & - & 6.49 & 1 & 351.11 & 312.49 & - & 91.7 & - & 3.41 \\
\hline 5 & 353.68 & 368.66 & 137 & 302.1 & 2.58 & 1.22 & 5 & 174.72 & 262.16 & 186.6 & 216.9 & 0.94 & 1.21 \\
\hline 15 & 276.67 & 395.24 & 370.4 & 219.3 & 0.75 & 1.80 & 15 & 285.23 & 277.18 & 561.8 & 215 & 0.51 & 1.29 \\
\hline
\end{tabular}

\begin{tabular}{|c|c|c|c|c|c|c|c|c|c|c|c|c|c|}
\hline \multirow{2}{*}{$\begin{array}{c}R M O H \\
\text { Day }\end{array}$} & \multicolumn{2}{|c|}{ Leachate Conc. (ng/L) } & \multicolumn{2}{|c|}{ Dilution } & \multicolumn{2}{|c|}{$\mathrm{LC}_{50}$ (ng/L) } & \multirow{2}{*}{\begin{tabular}{|c|} 
SWOH \\
Day
\end{tabular}} & \multicolumn{2}{|c|}{ Leachate Conc. (ng/L) } & \multicolumn{2}{|c|}{ Dilution } & \multicolumn{2}{|c|}{$\mathrm{LC}_{50}(\mathrm{ng} / \mathrm{L})$} \\
\hline & $\operatorname{Rep} 1$ & $\operatorname{Rep} 2$ & Rep 1 & $\operatorname{Rep} 2$ & Rep 1 & $\operatorname{Rep} 2$ & & $\operatorname{Rep} 1$ & Rep 2 & Rep 1 & $\operatorname{Rep} 2$ & $\operatorname{Rep} 1$ & $\operatorname{Rep} 2$ \\
\hline 1 & 683.2 & 509.0 & 383.1 & 216.9 & 1.78 & 2.35 & 1 & 296.7 & 219.5 & 243.3 & 199.2 & 1.22 & 1.10 \\
\hline 5 & 524.9 & 471.3 & 311.5 & 389.1 & 1.69 & 0.77 & 5 & 328.1 & 292.9 & 327.9 & 197.6 & 1.00 & 1.48 \\
\hline 15 & 613.6 & 402.3 & 625 & 479.6 & 0.98 & 0.84 & 15 & 470.6 & 319.5 & 671.1 & 561.8 & 0.70 & 0.57 \\
\hline
\end{tabular}

The higher mean $\mathrm{LC}_{50}$ in the runoff simulations suggests that additional suspended sediments may play a role in toxicity; either through bifenthrin adsorbed to suspended particles or increased sediment load reducing water quality. Mean turbidity readings on day 1 compared to the remaining 14 days averaged 53\% and $27 \%$ higher for pot leaching and field simulations, respectively. Results from Weston et al. (2009) 
suggested that suspended sediments were likely to reduce bifenthrin bioavailability, and estimated expected $\mathrm{LC}_{50}$ 's in runoff as $5-20 \mathrm{ng} / \mathrm{L}$. Our data indicate that bifenthrin is bioavailable within the pot leachate and resulting toxicity was similar to predictions based on initial water concentration tests. Results indicated that sediment may play a factor as $\mathrm{LC}_{50}$ values were lower at the beginning of runs when there was greater potential for a flush of sediment and organic matter from the pots and bins. Although, it is possible that tannins from sediment loads or pine bark increased mortality. Yang et al. (2006) revealed that up to $50 \%$ of bifenthrin was in a dissolved phase in surface-water runoff. In comparison, our results demonstrate that even with a substantial amount of sediments ( $>90$ NTU), much of the bifenthrin was bioavailable and toxic to H. azteca.

\section{Environmental Implications}

The threat of nursery and greenhouse site runoff with leachate similar to these experiments creates a significant problem for many aquatic organisms. Concentrations of bifenthrin in the pot and runoff simulations regularly exceeded $200 \mathrm{ng} / \mathrm{L}$, which is more than 100 times greater than the $\mathrm{LC}_{50}$ for $H$. azteca. Additionally, studies have shown that insecticides from stormwater and urban runoff accumulate in streambed sediments (Gan 2005, 2006, 2012; Hintzen et al. 2009; Weston et al. 2009). The aqueous photolysis halflife of bifenthrin ranges from 276-416 days and aquatic sediments for up to 16 months, indicating that accumulation of insecticide running off into streams is likely (Fecko 1999). Results from toxicity tests indicate that, on average, pot leachate will need to be diluted 200-300x before concentrations are no longer at the $\mathrm{LC}_{50}$ for $H$. azteca. Additional factors such as a longer overland flow over sediments, vegetation, and manmade surfaces may reduce the impact of these insecticides before entering a stream (Gan 
2012; Jiang et al. 2010; Bennett et al. 2005). In contrast, the high volume of leachate and runoff leaving a site during a storm or irrigation event significantly increases the possibility of toxic leachate reaching nearby surface waters and accumulating in stream bottom sediments.

\section{Bioretention Cell Media Insecticide Removal}

Column experiments allowed for investigation of removal efficiency of bifenthrin and fipronil from potting media leachate using bioretention cell media comprised of various combinations of sorted sand and compost. Results indicate that higher amounts of compost significantly improve removal of both insecticides from leachate. Mean reductions show $82 \%$ and $83 \%$ reduction $(S D=7)$ of bifenthrin in columns with $80 \%$ sand $/ 20 \%$ compost and $60 \%$ sand/40\% compost, respectively (Figure $3-7 a$ ).

Concentrations of bifenthrin leaving the columns were still 4-75x above the $\mathrm{LC}_{50}$ for $H$. azteca, however, depending on the initial influent concentrations (pot leaching $\mathrm{LC}_{50}=2.02$ ng/L). Strong reductions (mean of $72 \%, \mathrm{SD}=20$ ) of fipronil were only shown in the $60 / 40$ blend. Other bioretention cell media mixtures were highly variable for removal of fipronil, and mean reductions were less than 50\%. The 100\% sand and the 90/10 mixture resulted in a decrease of removal of bifenthrin and fipronil over time (Figure 3-7a and 37b). Additionally, a downward trend was shown for mean reduction of fipronil versus pore volumes (Figure 3-7b). 


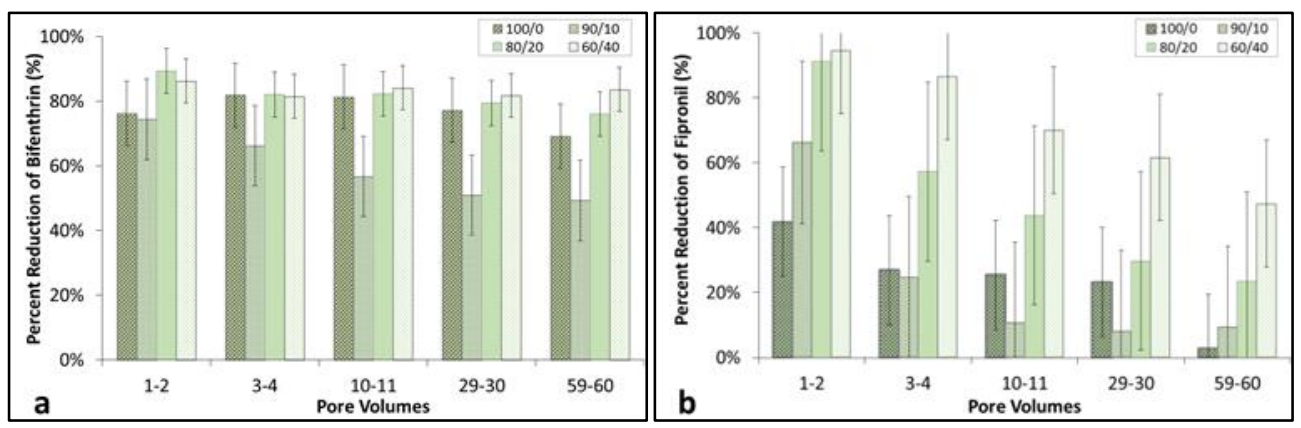

Figure 3-7. Represents mean ( \pm standard error) percent reduction of (a) bifenthrin and (b) fipronil concentrations through four bioretention cell media compositions: sand $(\%) /$ compost $(\%)$ by volume $(100 / 0,90 / 10,80 / 20,60 / 40)$ for 60 pore volumes.

The levels of insecticide in these column studies represent a worst-case scenario and dilution from rainwater and adsorption of insecticides to large particles may reduce the initial loadings entering the bioretention cell. Higher removals shown in the first two pore volumes may correlate to the media not being fully saturated, and therefore, higher retention time within the media. The fact that fipronil is moderately water soluble $\left(\mathrm{K}_{\mathrm{oc}}=825\right)$ and less likely to adsorb to organic matter may explain why removal efficiency became lower as more pore volumes of leachate were added. Levels of bifenthrin showed similar trends in the $100 \%$ and $90 \%$ sand. Due to the higher hydraulic conductivity of these two mixtures, leachate water moved through the column at a rate that may have reduced the potential for adsorbance of bifenthrin to sand particles. However, results showed that the 90/10 composition had reduced bifenthrin reduction and was significantly different $(\mathrm{p}<0.001)$. We think this may be due to the fact that the mean influent used during these runs was $56 \%$ higher than the other column test means overall. Influent was variable because leachate was taken from pots and concentrations depended on the specific pot that was leached for each column test. This conclusion may suggest 
that fluxes in concentrations may play a role in removal efficiencies with lower amounts of organic matter or compost.

One consideration of these column tests is the depth of media may play a large role in insecticide reduction. Increasing the retention time through the bioretention cell may significantly improve the removal efficiency of these insecticides. Flow rates of leachate through the column were faster in the $100 \%$ sand $(11 \mathrm{~cm} / \mathrm{min})$ compared to $60 \%$ sand $/ 40 \%$ compost $(5 \mathrm{~cm} / \mathrm{min})$, and may be indicative of removal efficiency of insecticides as the leachate has a longer contact time. Reduction of flow and sediment trapping and incorporation of vegetation has shown good efficiency in reducing pyrethroids (Bennett et al. 2005; Kabashima 2004). Furthermore, one recent study indicated that increased bioretention cell media depth vastly improves load reduction of nutrients, pathogens, and suspended solids (Brown et al. 2010). Bioretention cells typically contain 12-24 inches of sand/compost media, in addition to 3-6 inches of organic matter at the surface. Therefore, from our results and known adsorbent properties of the insecticides, removal efficiencies of bifenthrin and fipronil should increase with media depth.

\section{Conclusions}

Insecticide leaching potential from potted nursery stock at tree nurseries and greenhouse productions was investigated, along with a preliminary evaluation of the feasibility of bioretention cells for reducing insecticide concentrations in runoff. This project identified that insecticides such as bifenthrin and fipronil have a high potential to leach from nursery containers and affect water quality in nearby water bodies. In addition, bifenthrin was shown to be bioavailable and toxic to $H$. azteca, regardless of 
sediment influences. Given that a small fraction of bifenthrin was leached from the pots, leaching could be a significant toxicity problem long-term. Root Maker® pots with overhead irrigation produced the highest levels of insecticides leaving the pots. Use of drip irrigation with standard slick-wall pots may limit the leaching potential of insecticides, specifically, bifenthrin. Overall, bioretention cell media resulted in strong removal efficiencies for bifenthrin and for fipronil if enough organic matter is present in the system. Media with at least $20 \%$ compost by volume was shown to have the highest removal potential. As previous studies and this one indicate, introducing best management practices such as bioretention cells or vegetated swales can greatly reduce the amounts of insecticides leaving in runoff from agricultural sites.

Considering that the nursery industry has thousands of operations that sell nursery stock containers within the RIFA quarantine zone, insecticides such as bifenthrin and fipronil have the potential to create immense problems for aquatic environments if best management practices are not applied. The importance of implementing new remediation strategies in continuation with existing management practices such as using smaller quantities of water and insecticides is critical for optimal effectiveness of insecticide reduction. Additional studies in the future that could enhance best management practices include field monitoring of previously installed bioretention cells at a tree nursery or greenhouse facility, and a full-scale performance study of introducing pot leachate directly into a bioretention cell. 


\section{CHAPTER IV}

\section{LESSONS LEARNED}

This chapter provides reflection of the project, areas to improve the project, and ideas for future research. In addition, concepts were evaluated for how the results and conclusions of this research can be used in other applications outside of the nursery and greenhouse industry.

\section{Areas to Improve the Project}

Overall, the project provided an in-depth analysis of the transport and fate of two insecticides from potted nursery stock, and determined if these insecticides can potentially be removed from the runoff water through bioretention cell media. This section provides an overview of some areas that could be improved for future work.

Typically, only one insecticide is added to a potting media, but we wanted to investigate the fate of two common insecticides leaving the pots. The pots that were donated from the nursery were inoculated with $15 \mathrm{ppm}$ bifenthrin. We added fipronil at a rate of $1 \mathrm{ppm}$ because of economic reasons, and due to the fact that it was added as additional insecticide beyond the grant. I would recommend adding the same application of insecticide in a study such as this one due to the fact of comparison of one insecticide to the other. For our purpose, the results were beneficial because during the toxicity tests 
we discovered that adding fipronil at a lower level allowed us to investigate toxicity of bifenthrin without any other influences.

The bioretention cell media column tests provided introductory information about insecticide removal efficiency. Therefore, more research in the future should focus on scaling the project setup into similar dimensions as what is commonly installed at a bioretention cell site. A larger setup such as a box with 12-24 inch depth might have given us an ideal comparison to a bioretention cell in the field. Additionally, if time had allowed, sediment samples taken from the column media may have provided a sense of where the insecticides partitioned on the media.

\section{Ideas for Future Research}

This research represents a foundation of work that can possibly develop into a series of new projects that advance insecticide and pollutant management in the nursery industry, agriculture, and urban landscapes. For example, evolving this project into a field monitoring or larger-scale study would be beneficial to investigate systems that are similar to what is applied in the field. Other possible areas of research include research with previously or newly installed bioretention cells at nurseries or greenhouses, modeling, and investigating removal potential of other pesticides (herbicides, fungicides).

The first idea included spiking a bioretention cell during a number of years (or different aged BRC's) with pot leachate and collecting effluent from the outlet. This would be a very large, multi-year study, but might provide insight of how a complete system handles this leachate. In addition, lab column studies and transport/fate modeling could correspond with the field studies. Another possibility is collection of sediment 
cores from previously installed bioretention cells in areas that are suspected for insecticide use, and analyze for insecticide retention.

Modeling would include the transport and fate of insecticides leaving the pots and carried by surface runoff to nearby surface waters. Models would account for insecticide application rates, insecticide physical/chemical properties, turbidity, runoff velocity and volume, and composition of land (vegetated, concrete, compacted clay). In addition, models could also include the introduction of bioretention cells and vegetated channels for percent reduction under the same hydrological and physical conditions. Lastly, given that strong correlations were shown for turbidity and bifenthrin, studies including determining a relationship between turbidity and nursery insecticides might serve as a predictor for insecticide loads in runoff water.

Finally, investigating nutrient implications from increased compost load to adsorb pesticides might be beneficial to determine optimal insecticide removal efficiency and lowest nutrient leaching. Additionally, research on similar systems such as flow-through wetlands, constructed wetlands and vegetated filter strips for pesticide removal might provide information on alternatives for areas where nutrient management is critical, and/or bioretention cells may not serve as an ideal management strategy

\section{Project Outlook}

This project emphasizes use of bioretention cells for removal of pesticides from nurseries and greenhouses, but the use of bioretention cells as a best management practice for pesticides could be expanded into many different areas beyond the nursery industry. Applications of this research could be extended into residential and urban settings where 
there is potential for large amounts of pesticides applied to lawns and landscapes to leave in runoff. In addition, other crops such as grapes, vegetables, and ornamentals often require insecticides or herbicides use, and therefore, become a likely non-point pollution source.

The long-term outcome of this project and future projects should provide quality information to industries and state and federal agencies with regard of how to manage surface runoff from potential pesticide hotspots. Overall, this research identified the need for new and improved technology to limit toxic pesticides from entering nearby waterbodies and a potential remediation technology. Alternative solutions such as use of organic farming, or other integrated pest management strategies should first be considered when developing a project, although, this is often not possible and a pesticide is the best option for ensuring healthy crops. Therefore, best management practices should be considered in any instance to limit the aquatic risks associated with pesticide usage. 


\section{REFERENCES}

Amweg, Erin, Donald Weston, Jing You, et al (2006). Pyrethroid Insecticides and Sediment Toxicity in Urban Creeks from California and Tennessee. Environ. Sci. Technol. 40: 1700-1706.

Calcott, A. M. 2003. Imported fire ant: quarantine treatments for nursery stock and other regulated articles. Program aid no.1735. U.S. Dept. of Agr. Animal Plant Health Inspection Serv.

Connelly, Pete. (2001). Environmental Fate of Fipronil. California Environmental Protection Agency. Department of Pesticide Regulation.

Bennett, Erin, Matthew Moore, Charles Cooper, et al (2005). Vegetated Agricultural Drainage Ditches for the Mitigation of Pyrethroid-Associated Runoff. Environmental Toxicology and Chemistry. 24.9: 2121-2127.

Bobe, A., Meallier, P., Cooper, J-F, Coste, C. M. 1998b. Kinetics and mechanisms of abiotic degradation of fipronil (hydrolysis and photolysis). J. Agric. Food Chem. 46: 2834-2839.

Brown, R. A., \& Hunt III, W. F. (2010). Impacts of media depth on effluent water quality and hydrologic performance of undersized bioretention cells. Journal of Irrigation and Drainage Engineering, 137(3), 132-143.

Budd, R, S. Bondarenko, D. Haver, et al (2007). Occurrence and Bioavailability of Pyrethroids in a Mixed Land Use Watershed. Journal of Environmental Quality. 36: 1006-1012.

Budd, R., O'Geen, A., Goh, K. S., Bondarenko, S., \& Gan, J. (2009). Efficacy of constructed wetlands in pesticide removal from tailwaters in the Central Valley, California. Environmental Science \& Technology, 43(8), 2925-2930.

Delgado-Moreno, L., Wu, L., \& Gan, J. (2010). Effect of dissolved organic carbon on sorption of pyrethroids to sediments. Environmental Science \& Technology, 44(22), 8473-8478. 
Gan, J., Bondarenko, S., Oki, L., Haver, D., \& Li, J. X. (2012). Occurrence of fipronil and its biologically active derivatives in urban residential runoff. Environmental science \& technology, 46(3), 1489-1495.

Gan, Jay (2006). Pyrethroid insecticides in nursery runoff: Transport and impact on aquatic invertebrates. UC Water Resources Center Technical Completion Report: No. WRC Project W-968.

Gan, J, S.J Lee, P Liu, et al (2005). Distribution and Persistence of Pyrethroids in Runoff Sediments. Journal of Environmental Quality. 34: 836-841.

Gunasekara, A. S., \& Troung, T. (2007). Environmental fate of fipronil. Environmental Monitoring Branch.

Fecko, Andrew (1999). "Environmental Fate of Bifenthrin." Department of Pesticide Regulation: Environmental Monitoring and Pest Management Branch. 1-8.

Hintzen, E. P., Lydy, M. J., \& Belden, J. B. (2009). Occurrence and potential toxicity of pyrethroids and other insecticides in bed sediments of urban streams in central Texas. Environmental Pollution, 157(1), 110-116.

Hsieh, C. H., \& Davis, A. P. (2005). Evaluation and optimization of bioretention media for treatment of urban storm water runoff. Journal of Environmental Engineering, 131(11), 1521-1531.

Jiang, W., Gan, J., \& Haver, D. (2010). Sorption and desorption of pyrethroid insecticide permethrin on concrete. Environmental Science \& Technology, 45(2), 602-607.

Kabashima, J. N., Lee, S. J., Haver, D. L., Goh, K. S., Wu, L. S., \& Gan, J. (2004). Pesticide runoff and mitigation at a commercial nursery site. InACS Symposium series (Vol. 863, pp. 213-230). Washington, DC; American Chemical Society; 1999.

Lao, W. J., Arye, G., Ernst, F., Xu, Y. P., Bondarenko, S., Haver, D., \& Gan, J. (2008). Reduction of pyrethroid runoff from a commercial nursery. Synthetic Pyrethroids: Occurrence and Behavior in Aquatic Environments, 991, 426-445.

Lin, K., Haver, D., Oki, L., \& Gan, J. (2009). Persistence and sorption of fipronil degradates in urban stream sediments. Environmental Toxicology and Chemistry, 28(7), 1462-1468.

Lockley, T.C., and H.L. Collins (1990). Imported fire ant quarantine in the United States of America: past, present and future. J. Miss. Acad. Sci. 35: 2326. 
Mangiafico, Salvatore, Julie Newman, Donald Merhaut, et al (2009). Nutrients and Pesticides in Stormwater Runoff and Soil Water in Production Nurseries and Citrus and Avocado Groves in California. HorTechnology. 19: 360-367.

Miller, T.A. and V.L. Salgado. 1985. The mode of action of pyrethroids on insects, in The Pyrethroid Insecticides. Leahy, J.P., Ed., Taylor \& Francis, London. 43-97.

Rhône-Poulenc Ag Company. 1998. Application for Registration. Volume No. 52062071. Vol 1. Department of Pesticide Regulation, California Environmental Protection Agency, Sacramento, CA

Salgado V.L., S.N. Irving and T.A. Miller. 1983. The importance of nerve terminal depolarization in pyrethroid poisoning of insects. Pesticide Biochemical Physiology. 20: 169-182.

Siegfried, B.D. 1993. Comparative toxicity of pyrethroid insecticides to terrestrial and aquatic insects. Environmental Toxicology and Chemistry. 12:1683-1689.

Weston, D. P., Holmes, R. W., \& Lydy, M. J. (2009). Residential runoff as a source of pyrethroid pesticides to urban creeks. Environmental Pollution,157(1), 287-294.

Weston, D.P., R.W. Holmes, and J. You (2005). Aquatic Toxicity Due to Residential Use of Pyrethroid Insecticides. Environ. Sci. Technol.. 39: 9778-9784.

Yang, Weichun, Jianying Gan, and Wesley Hunter (2006). Effect of Suspended solids on Bioavailability of Pyrethroid Insecticides. Environmental Toxicology and Chemistry. 25.6. 1585-1591.

Ying, G. G., \& Kookana, R. S. (2006). Persistence and movement of fipronil termiticide with under-slab and trenching treatments. Environmental Toxicology and Chemistry, 25(8), 2045-2050.

Ying, G-G., Kookana, R. 2002. Laboratory and field studies on the degradation of fipronil in a soil. Aust. J. Soil Res. 40: 1095-1102.

USEPA (2000). Methods for Measuring the Toxicity and Bioaccumulation of Sedimentassociated Contaminants with Freshwater Invertebrates. EPA/600/R-99/064, second ed. Office of Science and Technology, Washington, DC.

USDA (2007). Imported Fire Ant 2007: Quarantine Treatments for Nursery Stock and Other Regulated Articles. Program Aid No. 1904. Animal and Plant Health Inspection Service. 
APPENDICES 


\section{APPENDIX A}

Potting Media Calculations

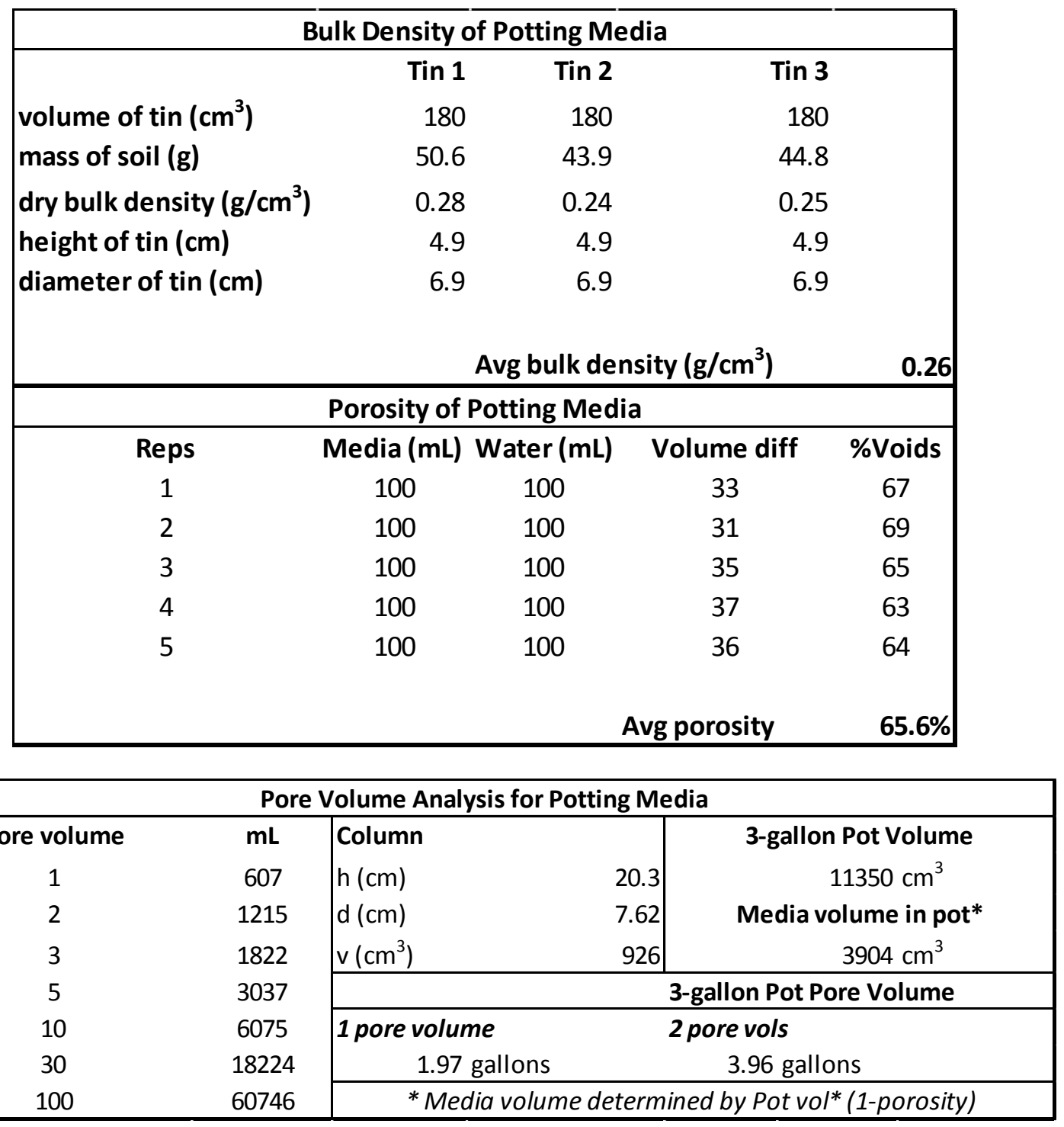




\section{APPENDIX B}

Potting Media Column Test Data

\begin{tabular}{|c|c|c|c|c|}
\hline \multicolumn{5}{|c|}{ COLUMN LEACHING EXPERIMENT DATA } \\
\hline Sample type & Sample ID & Bifenthrin & Fipronil & Median Turb \\
\hline & & \multicolumn{2}{|c|}{$n g / L$} & NTU \\
\hline 1 Sample & A1 & 571.0 & 90.5 & 25.4 \\
\hline 2 Sample & A2 & 270.9 & 79.1 & 9.34 \\
\hline 3 Sample & A3 & 178.4 & 88.1 & 8.83 \\
\hline 5 Sample & A4 & 8.89 & 10.5 & 5.88 \\
\hline 10 Sample & A5 & 11.6 & 10.4 & 3.00 \\
\hline 30 Sample & A6 & 29.2 & 64.7 & 3.69 \\
\hline 100 Sample & A7 & 19.5 & 24.1 & 1.04 \\
\hline Blank & A8 (Blank) & 6.70 & ND & 0.82 \\
\hline 1 Sample & A9 & 261.0 & 45.1 & 53.4 \\
\hline 2 Sample & A10 & 213.6 & 47.0 & 14.3 \\
\hline 3 Sample & A11 & 73.5 & 47.9 & 6.92 \\
\hline 5 Sample & A12 & 54.3 & 48.0 & 7.52 \\
\hline 10 Sample & A13 & 34.7 & 34.5 & 3.07 \\
\hline 30 Sample & A14 & 13.1 & 47.7 & 3.40 \\
\hline 100 Sample & A15 & 10.1 & 23.2 & 1.76 \\
\hline Blank & A16 & ND & ND & 0.36 \\
\hline 1 Sample & A17 & 276.4 & 37.6 & 17.5 \\
\hline 2 Sample & A18 & 135.9 & 54.7 & 6.08 \\
\hline 3 Sample & A19 & 135.9 & 63.7 & 3.22 \\
\hline 5 Sample & A20 & 111.0 & 66.4 & 3.32 \\
\hline 10 Sample & A21 & 36.2 & 45.6 & 1.00 \\
\hline 30 Sample & $\mathrm{A} 22$ & 18.7 & 32.7 & 0.70 \\
\hline 100 Sample & A23 & 14.4 & 21.9 & 0.45 \\
\hline Blank & A24 & ND & ND & 0.30 \\
\hline
\end{tabular}




\section{APPENDIX C}

Pot Leaching Experiment Data

\begin{tabular}{|c|c|c|c|c|c|c|c|c|c|c|c|c|}
\hline \multicolumn{13}{|c|}{ POT LEACHING SIMULATIONS INSECTICIDE CONCENTRATION DATA } \\
\hline \multirow{2}{*}{$\begin{array}{r}\text { Day } \\
\text { REP } 1 \\
\end{array}$} & \multirow{2}{*}{ ID } & \multirow{2}{*}{\multicolumn{2}{|c|}{ 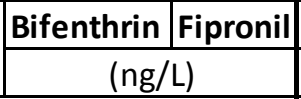 }} & \multirow{2}{*}{\multicolumn{2}{|c|}{\begin{tabular}{|l|l} 
Day & ID \\
REP 2 \\
\end{tabular}}} & \multirow{2}{*}{\multicolumn{3}{|c|}{ 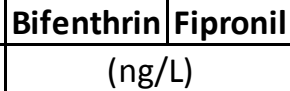 }} & \multirow{2}{*}{\multicolumn{2}{|c|}{\begin{tabular}{|l|l|} 
Day & ID \\
REP 3
\end{tabular}}} & \multirow{2}{*}{\multicolumn{2}{|c|}{$\begin{array}{c}\text { Bifenthrin } \mid \text { Fipronil } \\
(n g / 1)\end{array}$}} \\
\hline & & & & & & & & & & & & \\
\hline \multicolumn{4}{|c|}{ RMOH } & \multicolumn{5}{|c|}{ RMOH } & \multicolumn{4}{|c|}{ RMOH } \\
\hline \multicolumn{2}{|c|}{$1 \mathrm{~B} 1$} & 1192 & 270.5 & 1 & B27 & & 391.1 & 92.1 & 1 & B51 & 425.9 & 218.3 \\
\hline \multicolumn{2}{|c|}{2 B5 } & 511.0 & 519.2 & 2 & B31 & & 518.5 & 352.0 & 2 & B55 & 374.7 & 235.0 \\
\hline \multicolumn{2}{|c|}{3 B9 } & 488.2 & 449.0 & 3 & B35 & & 278.8 & 236.1 & 3 & B59 & 431.4 & 458.9 \\
\hline \multicolumn{2}{|c|}{5 B13 } & 526.7 & 440.5 & 5 & B39 & & 353.7 & 303.0 & 5 & B63 & 368.7 & 425.6 \\
\hline \multicolumn{2}{|c|}{$10 \mathrm{~B} 18$} & 260.2 & 329.7 & 10 & B43 & & 123.7 & 213.8 & 10 & B67 & 410.0 & 455.6 \\
\hline \multirow{2}{*}{\multicolumn{2}{|c|}{15 B22 }} & 367.5 & 306.8 & 15 & B47 & & 276.7 & 359.1 & 15 & B71 & 395.2 & 305.4 \\
\hline & & & & & & & & & & B71-D & 347.6 & 269.6 \\
\hline \multicolumn{4}{|c|}{ SWOH } & \multicolumn{5}{|c|}{ SWOH } & \multicolumn{4}{|c|}{ SWOH } \\
\hline 1 & B2 & 536.3 & 700.6 & 1 & B28 & & 351.1 & 40.4 & 1 & B52 & 312.5 & 99.8 \\
\hline 2 & B6 & 498.4 & 479.5 & 2 & B32 & & 207.3 & 194.2 & 2 & B56 & 300.4 & 150.3 \\
\hline 3 & B10 & 776.5 & 397.1 & 3 & B36 & & 248.9 & 167.7 & 3 & B60 & 260.6 & 284.4 \\
\hline 5 & B14 & 774.7 & 402.3 & 5 & B40 & & 174.7 & 334.6 & 5 & B64 & 262.2 & 238.3 \\
\hline 10 & B19 & 255.9 & 330.1 & 10 & B44 & & 141.6 & 256.0 & 10 & B68 & 136.8 & 194.7 \\
\hline \multirow[t]{2}{*}{15} & B23 & 301.4 & 273.0 & 15 & B48 & & 285.2 & 226.1 & 15 & B72 & 277.2 & 126.0 \\
\hline & & & & & B40-D & & 182.0 & 372.5 & & B52-D & 309.9 & 96.1 \\
\hline \multicolumn{4}{|c|}{ RMDI } & \multicolumn{5}{|c|}{ RMDI } & & & RMDI & \\
\hline 1 & B3 & 421.2 & 355.3 & 1 & B29 & & 161.8 & 103.6 & 1 & B53 & 146.1 & 184.0 \\
\hline 2 & B7 & 315.4 & 513.8 & 2 & B33 & & 182.2 & 282.5 & 2 & B57 & 157.4 & 361.8 \\
\hline 3 & B11 & 300.1 & 319.2 & 3 & B37 & & 211.5 & 263.7 & 3 & B61 & 129.8 & 421.1 \\
\hline 5 & B15 & 222.1 & 222.3 & 5 & B41 & & 243.8 & 312.3 & 5 & B65 & 179.0 & 258.5 \\
\hline 10 & B20 & 204.6 & 198.0 & 10 & B45 & & 74.5 & 147.3 & 10 & B69 & 238.1 & 272.3 \\
\hline 15 & B24 & 192.8 & 140.5 & 15 & B49 & & 151.6 & 191.1 & 15 & B73 & 252.5 & 260.9 \\
\hline & B24-D & 190.6 & 134.4 & & & & & & & & & \\
\hline & & SWDI & & & & SWD & & & & & SWDI & \\
\hline 1 & B4 & 151.2 & 444.2 & 1 & B30 & & 97.6 & 163.5 & 1 & B54 & 92.7 & 431.8 \\
\hline 2 & B8 & 345.5 & 424.7 & 2 & B34 & & 112.4 & 214.2 & 2 & B58 & 128.0 & 395.1 \\
\hline 3 & B12 & 305.6 & 304.3 & 3 & B38 & & 79.9 & 173.1 & 3 & B62 & 184.0 & 388.6 \\
\hline 5 & B16 & 204.8 & 193.9 & 5 & B42 & & 67.9 & 224.8 & 5 & B66 & 130.7 & 270.0 \\
\hline 10 & B21 & 130.8 & 103.8 & 10 & B46 & & 49.7 & 255.4 & 10 & B70 & 184.3 & 250.8 \\
\hline 15 & B25 & 184.4 & 147.1 & 15 & B50 & & 93.0 & 123.3 & 15 & B74 & 178.3 & 341.7 \\
\hline & B17-bl & 360.5 & 386.9 & & & & & & & & & \\
\hline & & Control & & & & Contr & & & RMOI & $I=$ Root I & Maker/Over & chead \\
\hline 1 & G1 & 107.9 & 0.5 & 1 & G4 & ND & & ND & SWOI & I= Slick -1 & wall/Overhe & \\
\hline 5 & G2 & 39.6 & 0.8 & 5 & G5 & ND & & ND & RMDI & $=\operatorname{Root} \mathrm{N}$ & laker/ Drip & \\
\hline 15 & G3 & 39.7 & 0.5 & 15 & G6 & ND & & ND & SWDI & $=$ Slick-v & vall/Drip & \\
\hline
\end{tabular}




\begin{tabular}{|c|c|c|c|c|c|}
\hline \multicolumn{6}{|c|}{ POT LEACHING SIMULATION WATER QUALITY DATA } \\
\hline \multicolumn{6}{|c|}{ Turbidity (NTU) } \\
\hline & \multicolumn{2}{|c|}{$\operatorname{Rep} 1^{\#}$} & $\operatorname{Rep} 2$ & $\operatorname{Rep} 3$ & Average \\
\hline \multicolumn{6}{|l|}{$\mathrm{RMOH}$} \\
\hline \multirow{6}{*}{$\overrightarrow{\widetilde{\pi}}$} & 1 & 17 & 7.2 & 4.3 & 9.5 \\
\hline & 2 & 2.7 & 6.1 & 2.2 & 3.7 \\
\hline & 3 & 2.7 & 5.3 & 2.8 & 3.6 \\
\hline & 5 & 2.1 & 4.2 & 3.7 & 3.3 \\
\hline & 10 & 2.3 & $*$ & 3.1 & 2.7 \\
\hline & 15 & 2.3 & 5.7 & 2.4 & 3.4 \\
\hline \multicolumn{6}{|l|}{ RMDI } \\
\hline \multirow{6}{*}{ 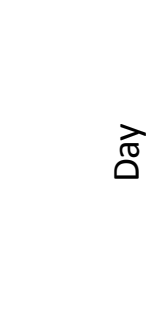 } & 1 & 3.5 & 1.3 & 1.9 & 2.2 \\
\hline & 2 & 2.7 & 1.5 & 1.4 & 1.9 \\
\hline & 3 & 1.6 & 2.2 & 2.0 & 1.9 \\
\hline & 5 & 1.1 & 2.2 & 1.8 & 1.7 \\
\hline & 10 & 1.7 & $*$ & 2.7 & 2.2 \\
\hline & 15 & 2.0 & 1.8 & 1.9 & 1.9 \\
\hline \multicolumn{6}{|l|}{ SWOH } \\
\hline \multirow{6}{*}{ 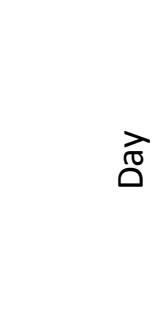 } & 1 & 3.4 & 3.5 & 4.8 & 3.9 \\
\hline & 2 & 3.5 & 3.2 & 2.7 & 3.1 \\
\hline & 3 & 4.3 & 3.1 & 2.8 & 3.4 \\
\hline & 5 & 2.3 & 2.1 & 3.6 & 2.7 \\
\hline & 10 & 2.5 & $*$ & 3.1 & 2.8 \\
\hline & 15 & 2.4 & 2.9 & 3.6 & 3.0 \\
\hline \multicolumn{6}{|l|}{ SWDI } \\
\hline \multirow{6}{*}{ ब } & 1 & 2.1 & 2.1 & 1.4 & 1.9 \\
\hline & 2 & 1.9 & 1.8 & 1.6 & 1.7 \\
\hline & 3 & 1.7 & 1.6 & 2.3 & 1.8 \\
\hline & 5 & 2.1 & 3.3 & 1.6 & 2.3 \\
\hline & 10 & 2.4 & 2.2 & 2.7 & 2.4 \\
\hline & 15 & 2.5 & $*$ & 2.4 & 2.4 \\
\hline \multicolumn{6}{|c|}{ * Lost data sheet } \\
\hline \multicolumn{6}{|c|}{ \# Rep 1-3 values are the median from 5 readings } \\
\hline \multicolumn{6}{|c|}{ SWOH=Slick-wall/Overhead, SWDI=Slick-wall/Drip } \\
\hline $\mathrm{RMOH}=\mathrm{Rc}$ & er/c & erhe & $\mathrm{RMDI}=$ & otmake & \\
\hline
\end{tabular}




\begin{tabular}{|c|c|c|c|c|}
\hline \multicolumn{5}{|c|}{ POT LEACHING SIMULATION WATER QUALITY DATA } \\
\hline \multicolumn{5}{|c|}{ pH } \\
\hline & Rep 1 & Rep 2 & Rep 3 & Average \\
\hline \multicolumn{5}{|l|}{$\mathrm{RMOH}$} \\
\hline \multirow{6}{*}{$\stackrel{\overrightarrow{0}}{0}$} & $1 *$ No data & 8.6 & 7.9 & 8.3 \\
\hline & $2 *$ No data & 8.8 & 7.4 & 8.1 \\
\hline & $3 *$ No data & 8.6 & 7.1 & 7.8 \\
\hline & $5 *$ No data & 8.7 & 6.9 & 7.8 \\
\hline & $10 *$ No data & 8.6 & 7.3 & 7.9 \\
\hline & $15 *$ No data & 8.7 & 7.3 & 8.0 \\
\hline \multicolumn{5}{|l|}{ RMDI } \\
\hline \multirow{6}{*}{$\overrightarrow{\widetilde{\pi}}$} & $1 *$ No data & 8.4 & 8.0 & 8.2 \\
\hline & $2 *$ No data & 8.8 & 7.4 & 8.1 \\
\hline & $3 *$ No data & 8.6 & 7.5 & 8.0 \\
\hline & $5 *$ No data & 8.7 & 7.0 & 7.9 \\
\hline & $10 *$ No data & 8.8 & 7.3 & 8.0 \\
\hline & $15 *$ No data & 8.7 & 7.3 & 8.0 \\
\hline \multicolumn{5}{|l|}{ SWOH } \\
\hline \multirow{6}{*}{ ঐే } & $1 *$ No data & 8.7 & 7.7 & 8.2 \\
\hline & $2 *$ No data & 8.9 & 7.0 & 8.0 \\
\hline & $3 *$ No data & 8.6 & 7.1 & 7.9 \\
\hline & $5 *$ No data & 8.9 & 6.7 & 7.8 \\
\hline & $10 *$ No data & 8.7 & 7.1 & 7.9 \\
\hline & $15 *$ No data & 8.8 & 8.1 & 8.4 \\
\hline \multicolumn{5}{|l|}{ SWDI } \\
\hline \multirow{6}{*}{ ঐ্ } & $1 *$ No data & 8.6 & 8.0 & 8.3 \\
\hline & $2 *$ No data & 9.1 & 7.0 & 8.0 \\
\hline & $3 *$ No data & 8.7 & 6.6 & 7.7 \\
\hline & $5 *$ No data & 8.8 & 6.9 & 7.9 \\
\hline & $10 *$ No data & 8.9 & 7.4 & 8.1 \\
\hline & $15 *$ No data & 7.8 & 7.2 & 7.5 \\
\hline \multirow{2}{*}{\multicolumn{3}{|c|}{$\begin{array}{c}\text { * Started } \mathrm{pH} \text { recordings after } \\
\text { 1st replicate }\end{array}$}} & Average & \\
\hline & & & Median & 8.0 \\
\hline \multicolumn{5}{|c|}{$\begin{array}{l}\text { SWOH=Slick-wall/Overhead, SWDI= Slick-wall/Drip } \\
\mathrm{RMOH}=\text { Rootmaker/Overhead, RMDI= Rootmaker/D }\end{array}$} \\
\hline
\end{tabular}




\begin{tabular}{|c|c|c|c|c|}
\hline \multicolumn{5}{|c|}{ POT LEACHING SIMULATION WATER QUALITY DATA } \\
\hline \multicolumn{5}{|c|}{ Specific Conductivity (uS/cm) } \\
\hline & $\operatorname{Rep} 1$ & Rep 2 & Rep 3 & Average \\
\hline \multicolumn{5}{|l|}{$\mathrm{RMOH}$} \\
\hline \multirow{6}{*}{$\vec{\pi}$} & $1 *$ No data & 943 & 722 & 833 \\
\hline & $2 *$ No data & 1190 & 1070 & 1130 \\
\hline & $3 *$ No data & 1020 & 1060 & 1040 \\
\hline & $5 *$ No data & 707 & 1000 & 854 \\
\hline & $10 *$ No data & 492 & 536 & 514 \\
\hline & $15 *$ No data & 868 & 496 & 682 \\
\hline \multicolumn{5}{|l|}{ RMDI } \\
\hline \multirow{6}{*}{$\stackrel{\widehat{\pi}}{\Delta}$} & $1 *$ No data & 753 & 833 & 793 \\
\hline & $2 *$ No data & 780 & 1020 & 900 \\
\hline & $3 *$ No data & 717 & 911 & 814 \\
\hline & $5 *$ No data & 725 & 754 & 740 \\
\hline & $10 *$ No data & 520 & 523 & 522 \\
\hline & $15 *$ No data & 699 & 511 & 605 \\
\hline \multicolumn{5}{|l|}{ SWOH } \\
\hline \multirow{6}{*}{ बे } & $1 *$ No data & 689 & 815 & 752 \\
\hline & $2 *$ No data & 907 & 1380 & 1140 \\
\hline & $3 *$ No data & 922 & 1310 & 1120 \\
\hline & $5 *$ No data & 808 & 955 & 882 \\
\hline & $10 *$ No data & 540 & 513 & 527 \\
\hline & $15 *$ No data & 790 & 491 & 641 \\
\hline \multicolumn{5}{|l|}{ SWDI } \\
\hline \multirow{6}{*}{$\stackrel{\vec{\pi}}{\Delta}$} & $1 *$ No data & 784 & 805 & 795 \\
\hline & $2 *$ No data & 826 & 1130 & 978 \\
\hline & $3 *$ No data & 750 & 973 & 862 \\
\hline & $5 *$ No data & 687 & 654 & 671 \\
\hline & $10 *$ No data & 522 & 504 & 513 \\
\hline & $15 *$ No data & 551 & 521 & 536 \\
\hline \multirow{2}{*}{\multicolumn{2}{|c|}{$\begin{array}{l}\text { * Started conductivity } \\
\text { readings after 1st replicate }\end{array}$}} & & Average & 785 \\
\hline & & & Median & \\
\hline \multicolumn{5}{|c|}{ SWOH=Slick-wall/Overhead, SWDI= Slick-wall/Drip } \\
\hline $\mathrm{RMOH}=\mathrm{R}$ & ker/Overhead, & $\mathrm{RMDI}=\mathrm{R}$ & otmaker/ & \\
\hline
\end{tabular}




\section{APPENDIX D}

Runoff Field Simulation Data

\begin{tabular}{|c|c|c|c|c|c|c|c|c|c|}
\hline \multicolumn{10}{|c|}{ RUNOFF SIMULATIONS INSECTICIDE CONCENTRATION DATA } \\
\hline \begin{tabular}{l|l} 
Day & ID \\
\end{tabular} & Bifenthrin & Fipronil & \begin{tabular}{|l|l|} 
Day & ID \\
\end{tabular} & Bifenthrin & fipronil & \begin{tabular}{|l|l|} 
Day & ID \\
\end{tabular} & Bife & thrin & fipronil \\
\hline \multirow{2}{*}{\multicolumn{3}{|c|}{$\begin{array}{l}\text { ng/L } \\
\text { RMOH }\end{array}$}} & REP 2 & $\mathrm{ng} / \mathrm{l}$ & & REP 3 & & $\mathrm{ng} / \mathrm{L}$ & \\
\hline & & & \multicolumn{3}{|c|}{ RMOH } & \multicolumn{4}{|c|}{ RMOH } \\
\hline $1 \mathrm{C} 1$ & 666.7 & 144.0 & $1 \mathrm{C} 25$ & 683.2 & 306.6 & 1 C49 & & 509.0 & 410.4 \\
\hline $2 \mathrm{C5}$ & 539.6 & 228.8 & $2 \mathrm{C} 29$ & 147.8 & 479.7 & $2 \mathrm{C} 53$ & & 361.5 & 511.1 \\
\hline $3 \mathrm{C9}$ & 769.8 & 259.5 & 3 C33 & 328.5 & 399.7 & $3 \mathrm{C} 57$ & & 738.3 & 547.3 \\
\hline $5 \mathrm{C} 13$ & 213.1 & 160.1 & 5 C37 & 524.9 & 380.6 & 5 C61 & & 471.3 & 613.7 \\
\hline $10 \mathrm{C} 17$ & 534.8 & 236.6 & $10 \mathrm{C} 41$ & 397.0 & 387.5 & $10 \mathrm{C} 65$ & & 599.9 & 489.1 \\
\hline \multirow[t]{2}{*}{$15 \mathrm{C} 21$} & 575.1 & 286.0 & 15 C45 & 613.6 & 292.1 & $15 \mathrm{C} 69$ & & 402.3 & 334.3 \\
\hline & & & 69-D & 215.7 & 396.4 & 49-D & & 520.2 & 401.2 \\
\hline \multicolumn{3}{|c|}{ SWOH } & \multicolumn{3}{|c|}{ SWOH } & \multicolumn{4}{|c|}{ SWOH } \\
\hline $1 \mathrm{C} 2$ & 358.0 & 114.2 & $1 \mathrm{C} 26$ & 296.7 & 304.9 & $1 \mathrm{C50}$ & & 219.5 & 297.6 \\
\hline $2 \mathrm{C} 6$ & 235.4 & 168.9 & 2 C30 & 308.7 & 391.7 & $2 C 54$ & & 341.9 & 408.3 \\
\hline $3 \mathrm{C} 10$ & 343.7 & 270.9 & $3 \mathrm{C} 34$ & 457.3 & 303.2 & $3 \mathrm{C58}$ & & 646.1 & 421.7 \\
\hline $5 \mathrm{C} 14$ & 558.4 & 248.4 & 5 C38 & 328.1 & 573.2 & $5 \mathrm{C} 62$ & & 292.9 & 448.4 \\
\hline $10 \mathrm{C} 18$ & 241.0 & 192.2 & $10 \mathrm{C} 42$ & 389.7 & 475.4 & $10 \mathrm{C} 66$ & & 361.4 & 414.6 \\
\hline $15 \mathrm{C} 22$ & 274.2 & 249.6 & $15 \mathrm{C} 46$ & 470.6 & 400.1 & 15 C70 & & 319.5 & 302.7 \\
\hline \multicolumn{3}{|c|}{ RMDI } & \multicolumn{3}{|c|}{ RMDI } & \multicolumn{4}{|c|}{ RMDI } \\
\hline $1 \mathrm{C} 3$ & 130.6 & 202.9 & $1 \mathrm{C} 27$ & 425.4 & 421.1 & 1 C51 & & 167.5 & 560.2 \\
\hline $2 \mathrm{C7}$ & 203.6 & 244.6 & 2 C31 & 269.8 & 419.8 & $2 C 55$ & & 250.1 & 513.2 \\
\hline 3 C11 & 317.8 & 263.1 & 3 C35 & 248.3 & 524.6 & 3 C59 & & 272.5 & 605.8 \\
\hline $5 \mathrm{C} 15$ & 397.7 & 298.5 & 5 C39 & 468.0 & 461.6 & $5 \mathrm{C} 63$ & & 290.4 & 529.1 \\
\hline 10 C19 & 246.5 & 377.4 & $10 \mathrm{C} 43$ & 283.2 & 351.9 & $10 \mathrm{C} 67$ & & 142.5 & 445.8 \\
\hline $15 \mathrm{C} 23$ & 231.5 & 317.5 & $15 \mathrm{C} 47$ & 220.4 & 279.7 & 15 C71 & & 138.7 & 364.8 \\
\hline C7-D & 220.0 & 299.8 & $40-D$ & 213.4 & 395.2 & & & & \\
\hline \multicolumn{3}{|c|}{ SWDI } & \multicolumn{3}{|c|}{ SWDI } & \multicolumn{4}{|c|}{ SWDI } \\
\hline $1 \mathrm{C} 4$ & 150.8 & 232.0 & $1 \mathrm{C} 28$ & 78.9 & 299.7 & 1 C52 & & 125.6 & 381.2 \\
\hline $2 \mathrm{C} 8$ & 168.2 & 195.4 & 2 C32 & 169.2 & 311.4 & $2 \mathrm{C56}$ & & 129.7 & 466.7 \\
\hline $3 \mathrm{C} 12$ & 217.8 & 245.3 & 3 C36 & 212.3 & 318.7 & $3 \mathrm{C} 60$ & & 242.4 & 492.6 \\
\hline 5 C16 & 205.0 & 235.5 & $5 \mathrm{C} 40$ & 178.1 & 414.5 & 5 C64 & & 227.3 & 447.9 \\
\hline $10 \mathrm{C} 20$ & 139.6 & 122.5 & $10 \mathrm{C} 44$ & 252.0 & 298.0 & $10 \mathrm{C} 68$ & & 189.6 & 375.3 \\
\hline \multirow[t]{2}{*}{$15 \mathrm{C} 24$} & 256.5 & 276.7 & $15 \mathrm{C} 48$ & 297.7 & 387.0 & $15 \mathrm{C} 72$ & & 80.5 & 301.0 \\
\hline & & & 28-D & 77.9 & 290.6 & & & & \\
\hline \multicolumn{3}{|c|}{ Control } & \multicolumn{3}{|c|}{ Control } & \multicolumn{4}{|c|}{ Control } \\
\hline F1 & ND & ND & F3 & ND & ND & F6 & ND & & ND \\
\hline \multirow[t]{2}{*}{$\mathrm{F} 2$} & ND & ND & F4 & ND & ND & F7 & ND & & ND \\
\hline & & & F5 & ND & ND & F8 & ND & & ND \\
\hline \multicolumn{10}{|c|}{$\begin{array}{c}\mathrm{RMOH}=\text { Root Maker/Overhead, SWOH= Slick-wall/Overhead, } \\
\text { RMDI= Root Maker/Drip, SWDI= Slick-wall/Drip }\end{array}$} \\
\hline
\end{tabular}




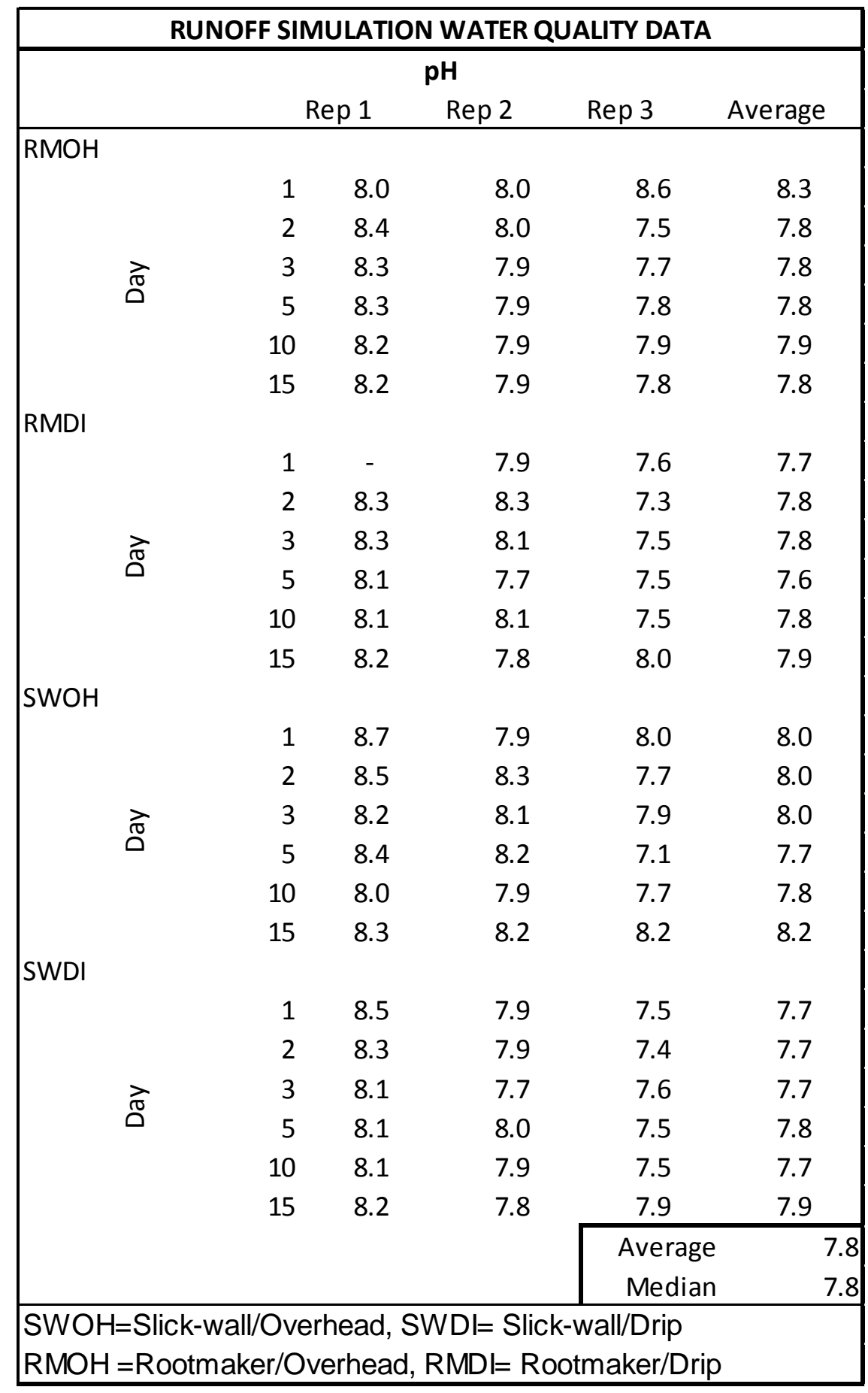




\begin{tabular}{|c|c|c|c|c|c|}
\hline \multicolumn{6}{|c|}{ RUNOFF SIMULATION WATER QUALITY DATA } \\
\hline \multicolumn{6}{|c|}{ Specific Conductivity (uS/cm) } \\
\hline & \multicolumn{2}{|c|}{ Rep 1} & Rep 2 & Rep 3 & Average \\
\hline \multicolumn{6}{|l|}{$\mathrm{RMOH}$} \\
\hline & 1 & 880 & 901 & 1002 & 951.5 \\
\hline \multirow{5}{*}{ \ָ } & 2 & 1089 & 1432 & 1546 & 1489 \\
\hline & 3 & 1233 & 2411 & 1630 & 2021 \\
\hline & 5 & 1146 & 2673 & 2446 & 2560 \\
\hline & 10 & 761 & 1106 & 1656 & 1381 \\
\hline & 15 & 1022 & 495 & 1000 & 747.5 \\
\hline \multicolumn{6}{|l|}{ RMDI } \\
\hline & 1 & - & 1079 & 1090 & 1085 \\
\hline & 2 & 899 & 1270 & 1550 & 1410 \\
\hline \multirow{4}{*}{ ঝু } & 3 & 997 & 1200 & 1270 & 1235 \\
\hline & 5 & 1120 & 1416 & 1340 & 1378 \\
\hline & 10 & 924 & 687 & 1310 & 999 \\
\hline & 15 & 985 & 527 & 1330 & 929 \\
\hline \multicolumn{6}{|l|}{ SWOH } \\
\hline & 1 & 827 & 875 & 866 & 871 \\
\hline \multirow{5}{*}{ SWIDI } & 2 & 841 & 1140 & 1420 & 1280 \\
\hline & 3 & 1050 & 1890 & 1660 & 1775 \\
\hline & 5 & 1230 & 763 & 2280 & 1522 \\
\hline & 10 & 1120 & 1190 & 1560 & 1375 \\
\hline & 15 & 1010 & 640 & 1780 & 1210 \\
\hline SWDI & & & & & \\
\hline \multirow{8}{*}{ ते } & 1 & 1100 & 983 & 943 & 963 \\
\hline & 2 & 1030 & 1350 & 1340 & 1345 \\
\hline & 3 & 979 & 1110 & 1010 & 1060 \\
\hline & 5 & 1070 & 1497 & 1180 & 1339 \\
\hline & 10 & 871 & 642 & 1120 & 881 \\
\hline & 15 & 1010 & 578 & 1130 & 906 \\
\hline & & & & Median & 1258 \\
\hline & & & & Average & 1279 \\
\hline \multicolumn{6}{|c|}{$\begin{array}{l}\text { SWOH=Slick-wall/Overhead, SWDI= Slick-wall/Drip } \\
\text { RMOH =Rootmaker/Overhead, RMDI= Rootmaker/Drip }\end{array}$} \\
\hline
\end{tabular}




\section{APPENDIX E}

Bioretention Cell Media Column Tests

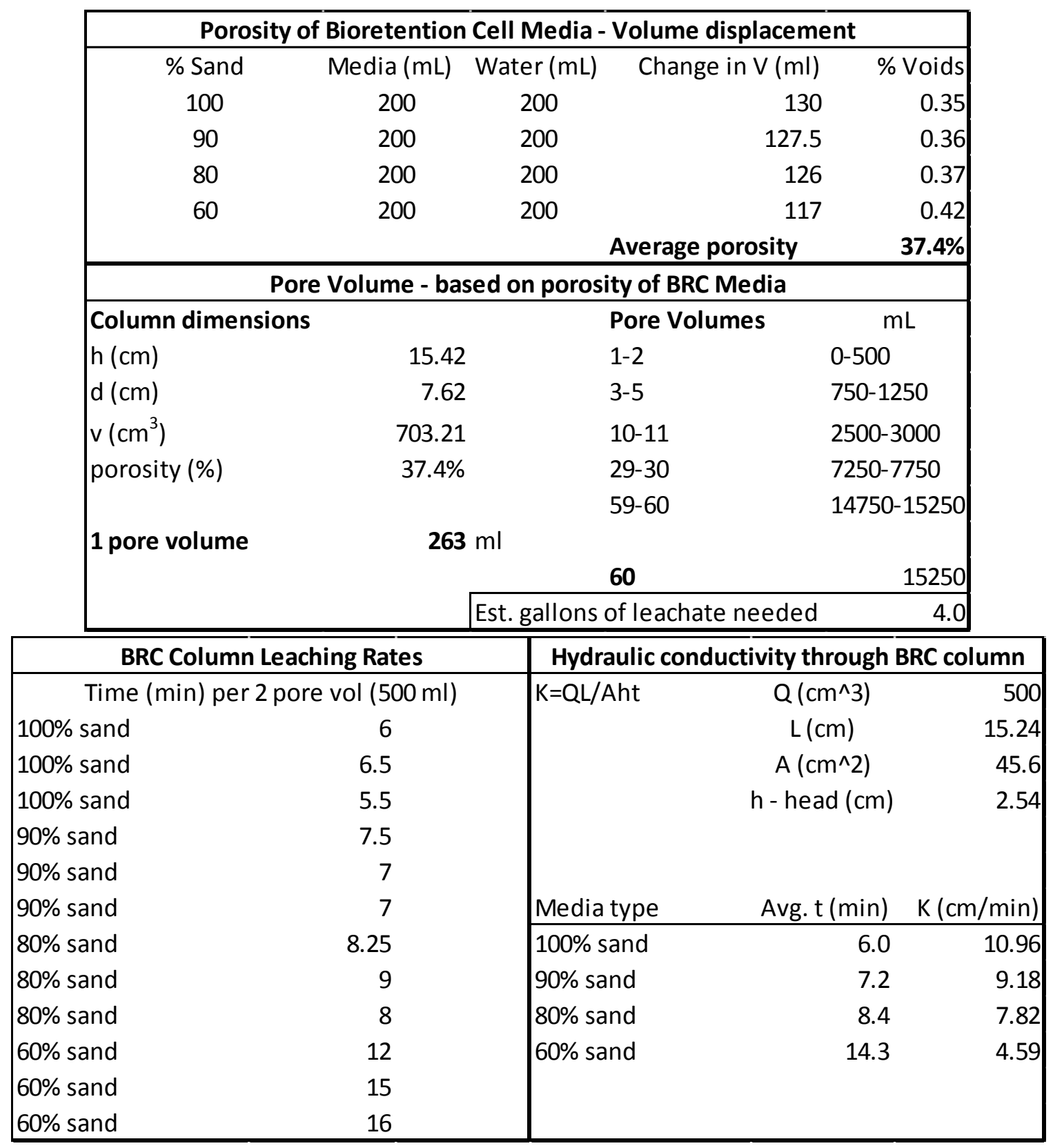




\begin{tabular}{|c|c|c|c|c|c|c|c|c|c|c|c|}
\hline \multirow{3}{*}{\multicolumn{2}{|c|}{$\frac{2}{\text { BIORETENTIC }}$}} & DN CEL & LL MEDI & IA COLUN & IN TE: & ST INSI & SECTICI & DE CONCE & ENTRA & ATION D & DATA \\
\hline & & Bif & Fip & \multirow{2}{*}{\multicolumn{2}{|c|}{ Pore vol ID }} & Bif & \multirow{2}{*}{$\begin{array}{l}\text { Fip } \\
\text { /L) }\end{array}$} & \multirow{2}{*}{\multicolumn{2}{|c|}{ Pore vol ID }} & \multirow[t]{2}{*}{ Bif } & \multirow{2}{*}{\begin{tabular}{|l} 
Fip \\
/L)
\end{tabular}} \\
\hline & & \multicolumn{2}{|c|}{ (ng/L) } & & & (ng/L) & & & & & \\
\hline \multicolumn{4}{|c|}{$100 \%$ Sand } & \multicolumn{4}{|c|}{$90 \%$ Sand $/ 10 \%$ Compost } & \multicolumn{4}{|c|}{$100 \%$ Sand } \\
\hline $1-2$ & D1 & 10.4 & 67.4 & $1-2$ & $\mathrm{D} 25$ & 76.5 & 130.1 & $1-2$ & D49 & 34.1 & 227.2 \\
\hline $3-5$ & D2 & 7.7 & 120.9 & $3-5$ & D26 & 106.7 & 262.9 & 3-5 & D50 & 30.6 & 268.2 \\
\hline 10-11 & D3 & 15.0 & 135.4 & $10-11$ & $\mathrm{D} 27$ & 115.7 & 232.1 & $10-11$ & D51 & 28.7 & 262.2 \\
\hline $29-30$ & D4 & 27.2 & 160.1 & $29-30$ & D28 & 123.3 & 241.6 & $29-30$ & D52 & 24.1 & 245.4 \\
\hline $59-60$ & D5 & 54.6 & 224.1 & $59-60$ & D29 & 149.3 & 303.0 & $59-60$ & D53 & 26.3 & 302.0 \\
\hline Influent & D6 & 132.4 & 206.2 & Influent & D30 & 231.5 & 281.1 & Influent & D54 & 132.6 & 333.6 \\
\hline \multicolumn{4}{|c|}{$100 \%$ Sand } & \multicolumn{4}{|c|}{ 90\% Sand $/ 10 \%$ Compost } & \multicolumn{4}{|c|}{$80 \%$ Sand $/ 20 \%$ Compost } \\
\hline $1-2$ & D7 & 70.0 & 224.3 & $1-2$ & D31 & 76.3 & 122.3 & $1-2$ & D55 & 7.6 & 18.1 \\
\hline $3-5$ & D8 & 47.0 & 242.7 & $3-5$ & D32 & 81.4 & 245.2 & 3-5 & D56 & 11.8 & 108.4 \\
\hline 10-11 & D9 & 42.6 & 240.8 & 10-11 & D33 & 115.9 & 351.5 & $10-11$ & D57 & 11.4 & 170.2 \\
\hline 29-30 & D10 & 54.7 & 240.8 & $29-30$ & D34 & 168.3 & 354.2 & $29-30$ & D58 & 11.2 & 197.7 \\
\hline $59-60$ & D11 & 58.1 & 281.2 & $59-60$ & D35 & 157.5 & 293.0 & $59-60$ & D59 & 9.3 & 186.4 \\
\hline Influent & D12 & 185.1 & 303.2 & Influent & D36 & 335.1 & 370.2 & Influent & D60 & 74.7 & 246.0 \\
\hline \multicolumn{4}{|c|}{$60 \%$ Sand $/ 40 \%$ Compost } & \multicolumn{4}{|c|}{ 90\% Sand/10\% Compost } & \multicolumn{4}{|c|}{$80 \%$ Sand $/ 20 \%$ Compost } \\
\hline $1-2$ & D13 & 16.5 & 6.0 & $1-2$ & D37 & 32.2 & 50.4 & $1-2$ & D61 & 12.8 & 40.6 \\
\hline $3-5$ & D14 & 21.5 & 28.0 & $3-5$ & D38 & 47.6 & 153.4 & 3-5 & D62 & 14.0 & 112.2 \\
\hline 10-11 & D15 & 22.9 & 84.8 & $10-11$ & D39 & 69.5 & 209.8 & $10-11$ & D63 & 21.0 & 225.4 \\
\hline $29-30$ & D16 & 22.0 & 105.4 & $29-30$ & D40 & 67.0 & 218.1 & $29-30$ & D64 & 18.2 & 230.2 \\
\hline $59-60$ & D17 & 20.9 & 118.6 & $59-60$ & D41 & 62.5 & 197.4 & $59-60$ & D65 & 25.6 & 274.3 \\
\hline Influent & D18 & 189.5 & 312.2 & Influent & D42 & 153.4 & 231.9 & Influent & D66 & 94.2 & 311.8 \\
\hline \multicolumn{4}{|c|}{$60 \%$ Sand $/ 40 \%$ Compost } & \multicolumn{4}{|c|}{$60 \%$ Sand $/ 40 \%$ Compost } & \multicolumn{4}{|c|}{$80 \%$ Sand $/ 20 \%$ Compost } \\
\hline $1-2$ & D19 & 36.6 & 44.3 & $1-2$ & D43 & 9.6 & 1.9 & $1-2$ & D67 & 9.8 & 22.8 \\
\hline 3-5 & D20 & 55.5 & 83.2 & $3-5$ & D44 & 10.4 & 12.3 & $3-5$ & D68 & 28.0 & 179.6 \\
\hline $10-11$ & D21 & 39.5 & 136.1 & $10-11$ & D45 & 10.7 & 42.1 & $10-11$ & D69 & 18.7 & 102.1 \\
\hline $29-30$ & $\mathrm{D} 22$ & 49.0 & 155.6 & $29-30$ & D46 & 12.5 & 66.8 & $29-30$ & D70 & 33.0 & 212.2 \\
\hline $59-60$ & D23 & 42.4 & 228.0 & $59-60$ & D47 & 11.4 & 98.4 & $59-60$ & D71 & 38.7 & 246.7 \\
\hline \multirow[t]{2}{*}{ Influent } & D24 & 178.1 & 336.8 & Influent & D48 & 79.7 & 188.8 & Influent & D72 & 119.8 & 373.7 \\
\hline & & & & & & & & Blnk/800 & D73 & 668.2 & 836.0 \\
\hline
\end{tabular}




\begin{tabular}{|c|c|c|c|c|c|c|c|c|c|c|c|}
\hline \multicolumn{12}{|c|}{ BIORETENTION CELL MEDIA COLUMN TEST PERCENT (\%) REDUCTION } \\
\hline \multirow{2}{*}{\multicolumn{2}{|c|}{ Pore vol ID }} & Bif & Fip & \multirow[t]{2}{*}{ Pore vol } & \multirow[t]{2}{*}{ ID } & Bif & Fip & \multirow[t]{2}{*}{ Pore vol } & \multirow[t]{2}{*}{ ID } & \multirow{2}{*}{\multicolumn{2}{|c|}{\begin{tabular}{|l|l|} 
Bif & Fip \\
(ng/L)
\end{tabular}}} \\
\hline & & \multicolumn{2}{|c|}{ (ng/L) } & & & \multicolumn{2}{|c|}{ (ng/L) } & & & & \\
\hline \multicolumn{4}{|c|}{$100 \%$ Sand } & \multicolumn{4}{|c|}{ 90\% Sand/10\% Compost } & \multicolumn{4}{|c|}{$100 \%$ Sand } \\
\hline $1-2$ & D1 & $92 \%$ & $67 \%$ & $1-2$ & $\mathrm{D} 25$ & $67 \%$ & $54 \%$ & $1-2$ & D49 & $74 \%$ & $32 \%$ \\
\hline 3-5 & D2 & $94 \%$ & $41 \%$ & 3-5 & D26 & $54 \%$ & $6 \%$ & $3-5$ & D50 & $77 \%$ & $20 \%$ \\
\hline $10-11$ & D3 & $89 \%$ & $34 \%$ & $10-11$ & $\mathrm{D} 27$ & $50 \%$ & $17 \%$ & $10-11$ & D51 & $78 \%$ & $21 \%$ \\
\hline $29-30$ & D4 & $79 \%$ & $22 \%$ & $29-30$ & D28 & $47 \%$ & $14 \%$ & $29-30$ & D52 & $82 \%$ & $26 \%$ \\
\hline $59-60$ & D5 & $59 \%$ & $-9 \%$ & $59-60$ & D29 & $36 \%$ & $-8 \%$ & $59-60$ & D53 & $80 \%$ & $9 \%$ \\
\hline \multicolumn{4}{|c|}{$100 \%$ Sand } & \multicolumn{4}{|c|}{$90 \%$ Sand $/ 10 \%$ Compost } & \multicolumn{4}{|c|}{$80 \%$ Sand $/ 20 \%$ Compost } \\
\hline $1-2$ & D7 & $62 \%$ & $26 \%$ & $1-2$ & D31 & $77 \%$ & $67 \%$ & $1-2$ & D55 & $90 \%$ & $93 \%$ \\
\hline 3-5 & D8 & $75 \%$ & $20 \%$ & $3-5$ & D32 & $76 \%$ & $34 \%$ & $3-5$ & D56 & $84 \%$ & $56 \%$ \\
\hline $10-11$ & D9 & $77 \%$ & $21 \%$ & $10-11$ & D33 & $65 \%$ & $5 \%$ & $10-11$ & D57 & $85 \%$ & $31 \%$ \\
\hline $29-30$ & D10 & $70 \%$ & $21 \%$ & $29-30$ & D34 & $50 \%$ & $4 \%$ & $29-30$ & D58 & $85 \%$ & $20 \%$ \\
\hline $59-60$ & D11 & $69 \%$ & $7 \%$ & $59-60$ & D35 & $53 \%$ & $21 \%$ & $59-60$ & D59 & $88 \%$ & $24 \%$ \\
\hline \multicolumn{4}{|c|}{$60 \%$ Sand $/ 40 \%$ Compost } & \multicolumn{4}{|c|}{$90 \%$ Sand $/ 10 \%$ Compost } & \multicolumn{4}{|c|}{$80 \%$ Sand $/ 20 \%$ Compost } \\
\hline $1-2$ & D13 & $91 \%$ & $98 \%$ & $1-2$ & D37 & $79 \%$ & $78 \%$ & $1-2$ & D61 & $86 \%$ & $87 \%$ \\
\hline $3-5$ & D14 & $89 \%$ & $91 \%$ & 3-5 & D38 & $69 \%$ & $34 \%$ & $3-5$ & D62 & $85 \%$ & $64 \%$ \\
\hline 10-11 & D15 & $88 \%$ & $73 \%$ & $10-11$ & D39 & $55 \%$ & $10 \%$ & $10-11$ & D63 & $78 \%$ & $28 \%$ \\
\hline $29-30$ & D16 & $88 \%$ & $66 \%$ & $29-30$ & D40 & $56 \%$ & $6 \%$ & $29-30$ & D64 & $81 \%$ & $26 \%$ \\
\hline $59-60$ & D17 & $89 \%$ & $62 \%$ & $59-60$ & D41 & $59 \%$ & $15 \%$ & $59-60$ & D65 & $73 \%$ & $12 \%$ \\
\hline \multicolumn{4}{|c|}{$60 \%$ Sand $/ 40 \%$ Compost } & \multicolumn{4}{|c|}{$60 \%$ Sand/40\% Compost } & \multicolumn{4}{|c|}{$80 \%$ Sand $/ 20 \%$ Compost } \\
\hline $1-2$ & D19 & $79 \%$ & $87 \%$ & $1-2$ & D43 & $88 \%$ & $99 \%$ & $1-2$ & D67 & $92 \%$ & $94 \%$ \\
\hline 3-5 & D20 & $69 \%$ & $75 \%$ & 3-5 & D44 & $87 \%$ & $94 \%$ & $3-5$ & D68 & $77 \%$ & $52 \%$ \\
\hline 10-11 & D21 & $78 \%$ & $60 \%$ & $10-11$ & D45 & $87 \%$ & $78 \%$ & $10-11$ & D69 & $84 \%$ & $73 \%$ \\
\hline $29-30$ & $\mathrm{D} 22$ & $73 \%$ & $54 \%$ & $29-30$ & D46 & $84 \%$ & $65 \%$ & $29-30$ & D70 & $72 \%$ & $43 \%$ \\
\hline $59-60$ & $\mathrm{D} 23$ & $76 \%$ & $32 \%$ & $59-60$ & D47 & $86 \%$ & $48 \%$ & $59-60$ & D71 & $68 \%$ & $34 \%$ \\
\hline
\end{tabular}




\section{APPENDIX F}

Project Drawings

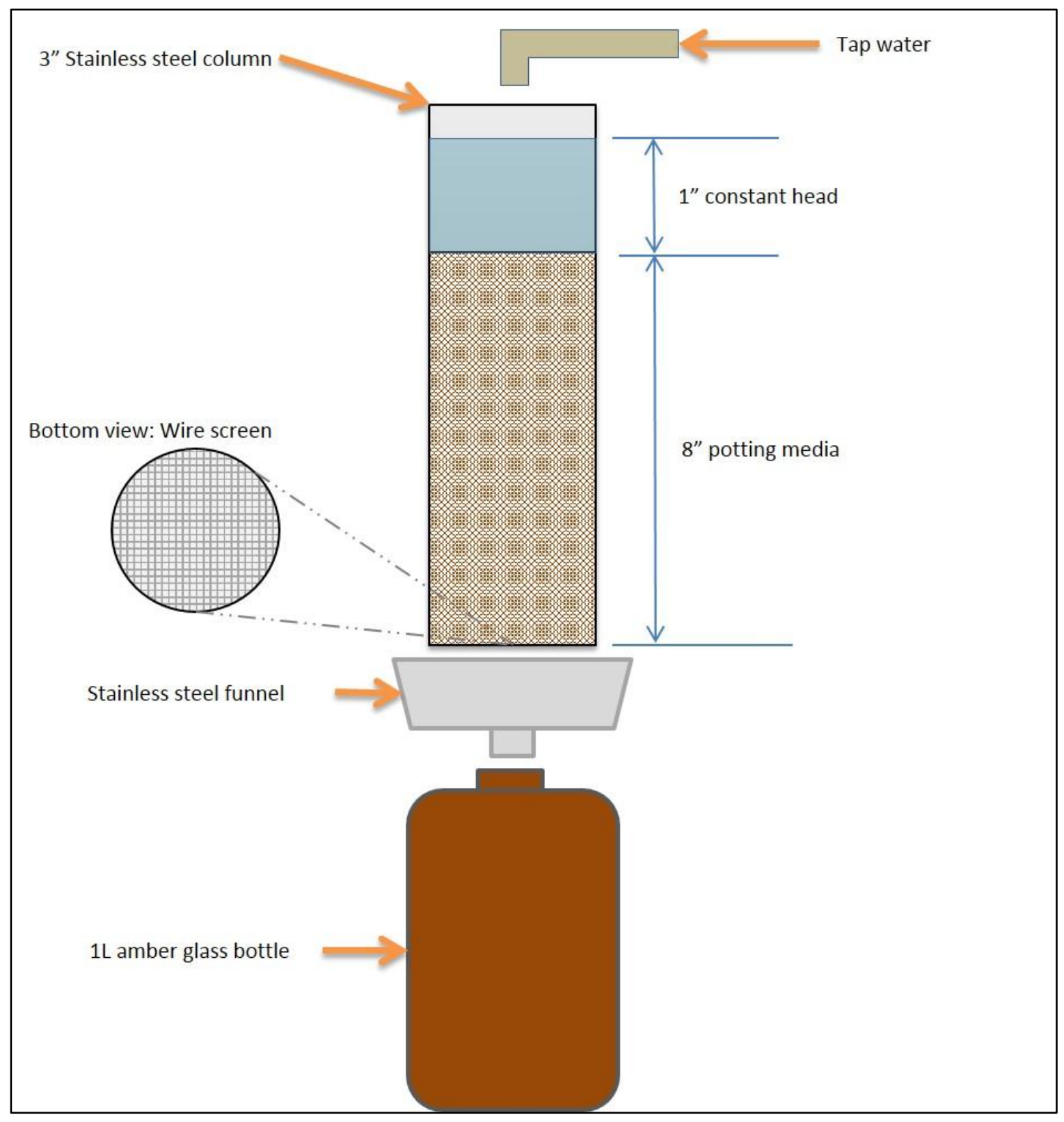

Potting Media Column Leaching Setup 


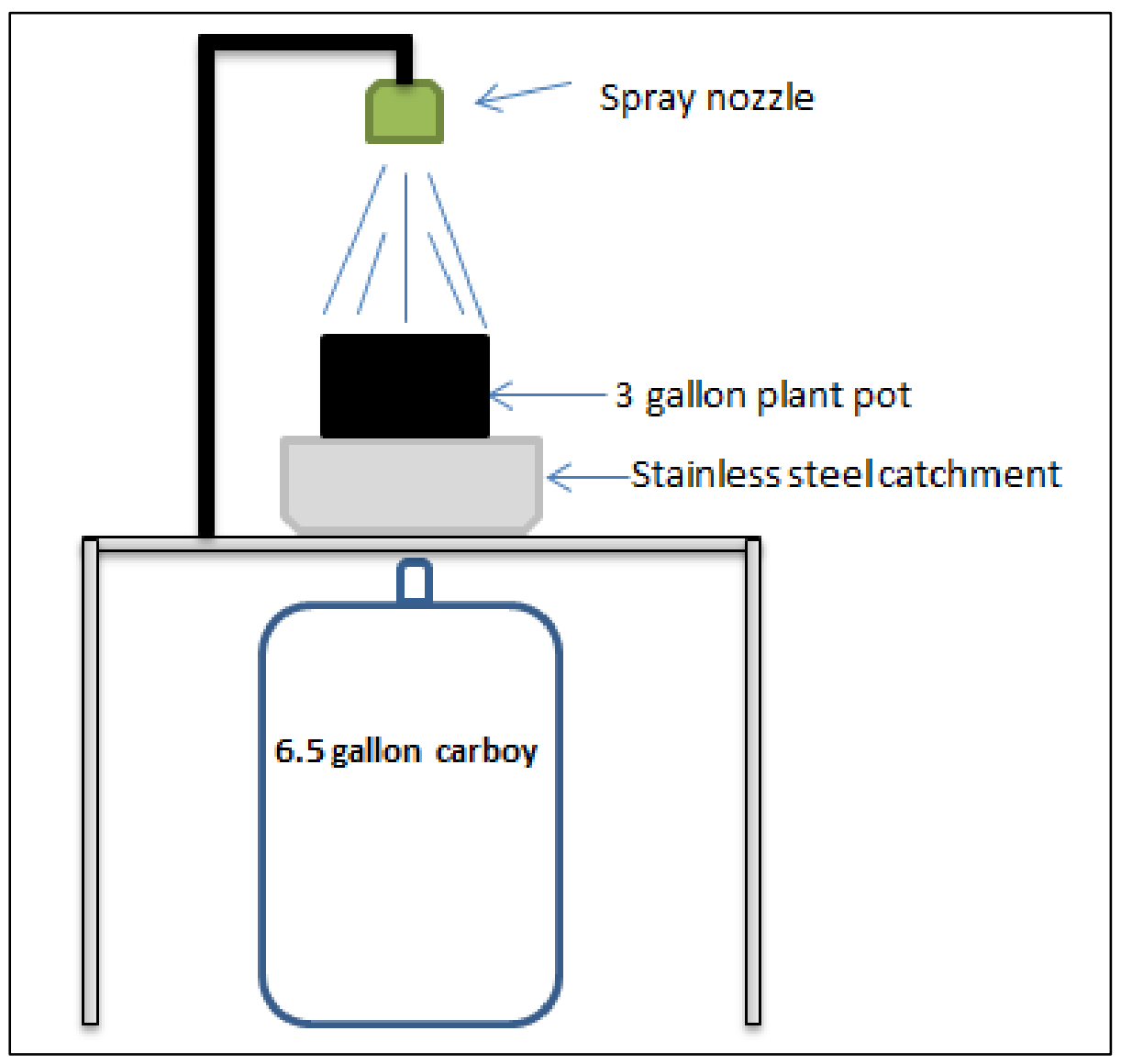

Pot Leaching Setup 


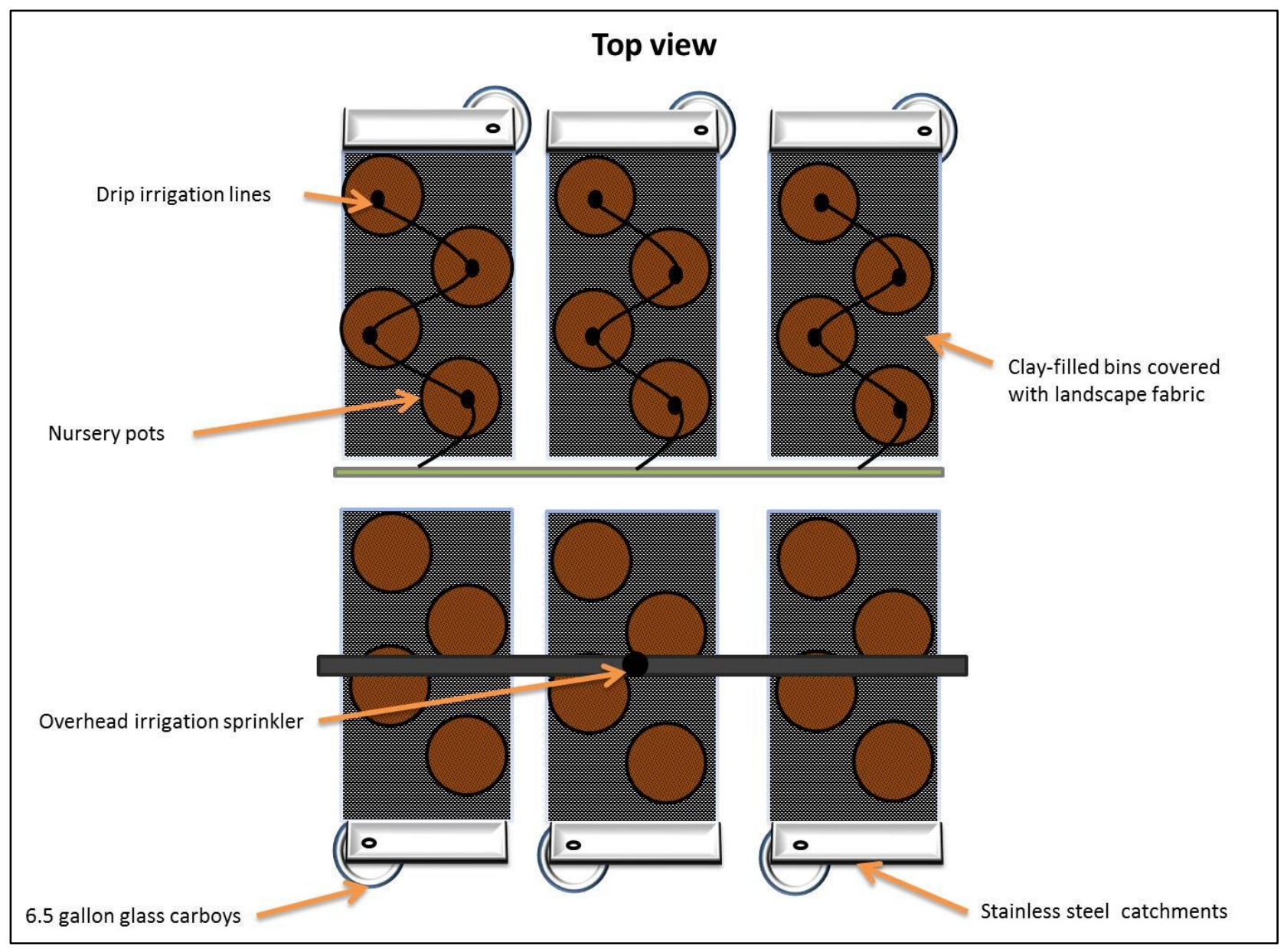

Runoff Simulation Setup 


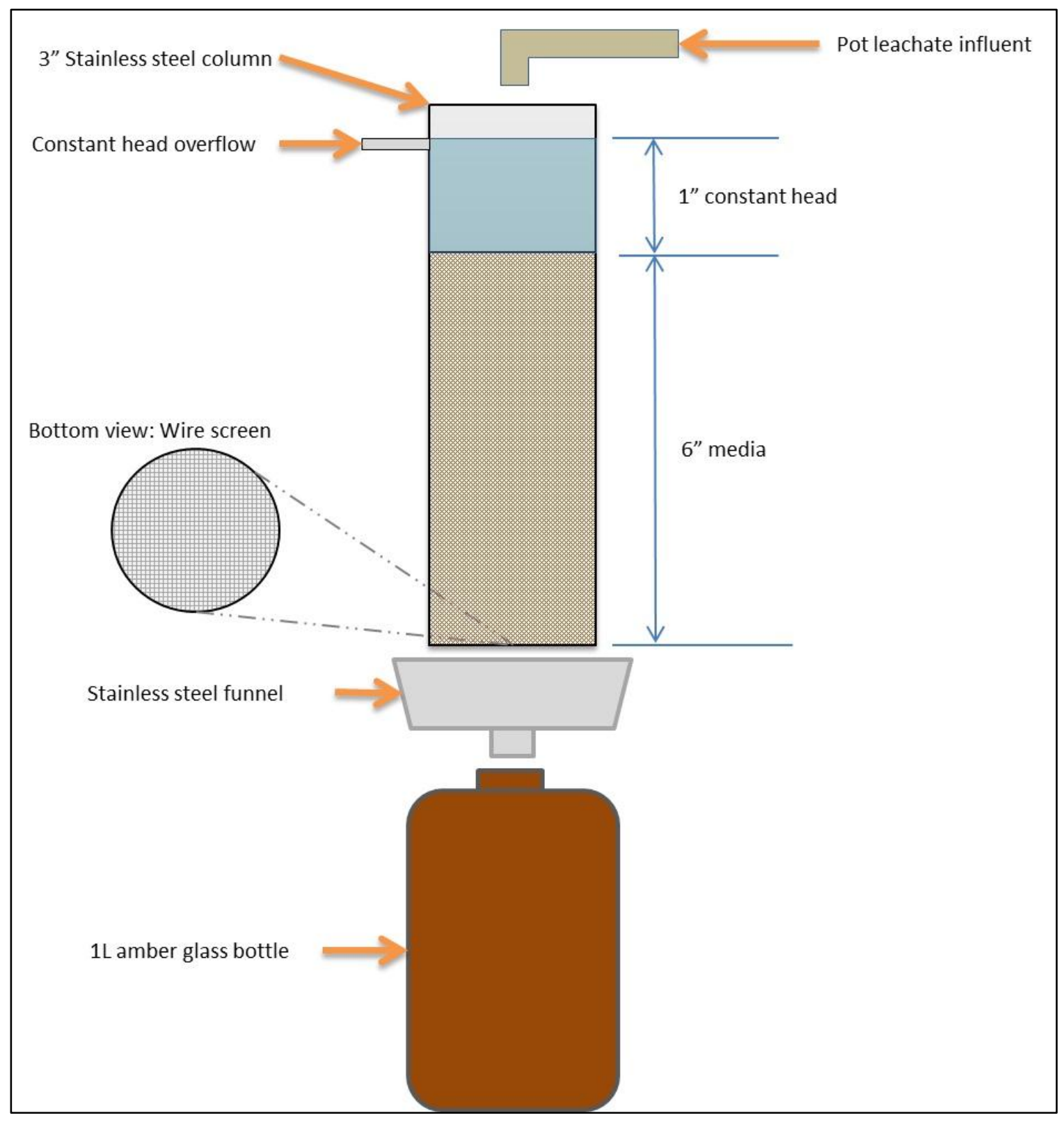

Bioretention Cell Media Column Test Setup 
VITA

\section{GRANT MATTHEW GRAVES}

Candidate for the Degree of

Master of Science

Thesis: INVESTIGATION OF INSECTICIDE LEACHING FROM POTTED

NURSERY STOCK AND AQUATIC HEALTH BENEFITS OF

BIORETENTION CELLS RECEIVING NURSERY RUNOFF

\section{Major Field: ENVIRONMENTAL SCIENCE}

Biographical:

Personal Data: From Tishomingo, OK. Son of Kerry and Donna Graves

Education: Bachelor of Science in Environmental Science at Oklahoma State University, Stillwater, OK in 2011. Completed Requirements for the Master of Science in Environmental Science at Oklahoma State University, Stillwater, OK, in December 2013.

Experience: Graduate Research Assistant at Oklahoma State University, Undergraduate Research Assistant at Oklahoma State University, Intern at Oklahoma Conservation Commission, Teaching Assistant at Oklahoma State University, Intern at Student Conservation Association

Professional Memberships: American Society of Agricultural and Biological Engineers, Oklahoma State Society of Environmental Scientists, Phi Kappa Phi Honor Society 